\title{
The Corporate Pro Se Litigant
}

\begin{abstract}
SUNEAL BEDI ${ }^{*}$
Corporations, partnerships, and all other business organizations cannot appear pro se in either criminal or civil proceedings. Business organizations must use a hired lawyer to defend lawsuits. This arbitrary and outdated rule has not been revisited in over 150 years. This Article is the first to lay out in detail the current state of corporate pro se rights. It then debunks the current rationales offered for the prohibition on corporate self-representation. Finally, it offers a novel argument that business organizations should be given a constitutional pro se right to litigate their own cases.

In doing this, it draws upon the importance of the individual constitutional due process rights that exist to protect against government deprivations of life and liberty. Individuals in the corporate context are equally at stake of deprivations of life and liberty given corporate lawsuits. These deprivations are particularly salient for nonexecutive employees. As such, this Article argues that if we really care about the individual pro se right, we should grant corporations a similar due process right.
\end{abstract}

I. INTRODUCTION

II. CoRPorate vS. Individual Pro SE RIGHTS ..................................83

III. RATIONALES FOR DENYING CORPORATIONS Pro Se RightS............89

A. The Agency Rationale ...........................................................89

B. The Public Policy Rationale .....................................................96

IV. Rationales FOR THE Pro Se Right ............................................98

A. The Magna Carta and the Original Founders ........................99

B. American Pro Se Due Process Rights ..................................101

V. The Corporate Pro Se Litigant ................................................106

A. Effects of Corporate Criminal/Civil Litigation on

Individuals

B. Critiques of the Corporate Pro Se Right

1. A Manager Is Not Capable of Representing a

* Assistant Professor of Business Law and Ethics, Indiana University, Affiliated Faculty at The Center for Law, Society, and Culture at Indiana University Maurer School of Law. I would like to thank David Zaring, Nicholas Cornell, Will Marra, Matt Greenfield, Aneil Kovvali, Margaret Lai, Sonu Bedi, Amy Sepinwall, and Vince Buccola for helpful comments and suggestions. A version of this article was presented at the Academy of Legal Studies in Business Annual Conference at the University of Pennsylvania. I thank the participants for their comments. I thank the Marc and Diane Spilker Corporate Governance Fellowship for generously providing funding for this research. Finally, I'd like to thank the editors at the Ohio State Law Journal for their diligent editing and writing edits. 
Corporation

\section{INTRODUCTION}

Zen Bakeries, LLC was a small bakery owned by a young couple. ${ }^{1}$ The two were the only owners (i.e., members), in the company. ${ }^{2}$ A bakery with a similar name (Zen Bakery) sued the company for trademark infringement, ${ }^{3}$ naming both the couple personally and the LLC as defendants and asked for a preliminary injunction. ${ }^{4}$ The two missed their court hearing and did not respond to the compliant, and the court therefore granted the preliminary injunction against them. ${ }^{5}$ When they eventually appeared before the judge, the injunction was removed pending the couple's response. ${ }^{6}$ However, the judge notified the couple that the injunction still stood against the LLC. ${ }^{7}$ This was because the LLC itself had not "appeared." the couple, being the only owners, thought they were representing the business entity. The court, however, indicated that the preliminary injunction would still apply to the bakery if the baker did not appear with counsel, even though both owners were present on behalf of the corporation. ${ }^{9}$ To the couple's ultimate surprise and frustration, the company could not appear pro se. ${ }^{10}$

This might strike the reader or company owner as inefficient and bizarre. However, this is the current state of the law. Corporations, and any business organizations for that matter (partnerships, LLCs, non-profits), cannot appear

${ }^{1}$ See Complaint at 1-2, Drake v. Zen Bakeries, LLC, No. 1-14-CV-00999 (S.D.N.Y. 2014), 2014 WL 916337[hereinafter Drake Complaint]. See generally About Us, BAKEDSOME ARTISINAL FLATBREAD \& PIES, https:/www.bakedsome.com/about-us/ [https://perma.cc/Q5WH-2Y7N] (referencing the the members of Zen in their current bakery as "young pathfinders" at the beginning of their baking journey).

2 Drake Complaint, supra note 1 , at 1 .

3 See id. at 2-3.

${ }^{4} I d$. at $1,7-8$.

${ }^{5}$ See Order at 1-2, Drake v. Zen Bakeries, LLC., No. 1-14-CV-00999 (S.D.N.Y. Mar. 31,2014 ) [hereinafter Order Filed March 31, 2014].

${ }^{6}$ See Order, Drake v. Zen Bakeries, LLC., No. 14-CV-00999 (S.D.N.Y. Apr. 30, 2014) [hereinafter Order Filed April 30, 2014].

7 See id.

${ }^{8}$ This was not explicit in the motion and hearing but given, as the Article elucidates, that companies cannot appear pro se, the couple needed to hire counsel for the LLC to legally appear before the court.

${ }^{9}$ See Order Filed April 30, 2014, supra note 6.

${ }^{10} \mathrm{Id}$. The couple ended up losing the lawsuit in the end. Stipulated Final Judgement at 1; Drake v. Zen Bakeries, LLC, No. 14-CV-00999 (S.D.N.Y. 2014). 
pro se in a court proceeding. ${ }^{11}$ Corporations, ${ }^{12}$ instead, must be, at all times, represented by a lawyer. ${ }^{13}$ The Supreme Court has even been affected by this archaic rule in its most recent term when it issued a for-cause motion against a lawyer who signed a writ of certiorari on behalf of a sole-shareholder. ${ }^{14}$

This raises the question, why do individuals have a right to proceed pro se but corporations do not? The scholarship discussing corporate pro se rights is all but nonexistent. ${ }^{15}$ This Article is the first to formally lay out the rules for corporate counsel. It seeks to elucidate the rationales for treating corporations and individuals differently in this context. It then provides a novel framework for evaluating the corporate pro se right by debunking these rationales. Lastly, it offers a rationale for extending the pro se right to corporations.

In the past fifty years, corporate rights have drastically expanded. The academic movement termed "corporate personhood" seeks to equate corporations as people, at least in so far as the law treats them. ${ }^{16}$ It's common

11 There are several sources of law of this proposition, but the oldest and most relied upon is Osborn v. Bank of U.S., 22 U.S. (9 Wheat.) 738, 830 (1824), and see also Simbraw, Inc. v. United States, 367 F.2d 373, 374 (3d Cir. 1966) (per curiam) (discussing several circuit court opinions relying on Osborn to support the well-established rule that "a corporation can appear in a court of record only by an attorney at law").

${ }^{12}$ I use the word "corporation" here to mean any business organization including partnerships, LLCs, and LLPs.

13 Osborn, 22 U.S. (9 Wheat.) at 830.

14 There, Professor Schindler, the founder of a telecommunications and technology company, attempted to bring a copyright lawsuit on behalf of his limited liability corporation. See Response to Order to Show Cause at 6, 9-10, In re Discipline of Shipley, $135 \mathrm{~S}$. Ct. 779 (2014) (mem.) (No. 14-D-2827). He, however, was not able to given the current state of the law and was accused of bullying his lawyer, the famous Howard Shipley, to sign off on his writ of certiorari to the Supreme Court. See id. at 1 . The appeal, however, did not conform to the guidelines set forth by the Court and included several instances of technical jargon and un-interpretable argumentation. See id. at 15 . As a result, the Court (for the first time in over fifty years) filed a motion against Shipley to show cause "within 40 days, why he should not be sanctioned for his conduct as a member of the Bar of this Court in connection with the petition" for a writ of certiorari. In re Discipline of Shipley, 135 S. Ct. 779, 779-80 (2014) (mem.), discharged by In re Shipley, 135 S. Ct. 1589-90 (2015) (mem.).

$15 \mathrm{~A}$ few short notes appear in law reviews, these are however very old and do not provide for a coherent rationale for allowing corporations to proceed pro se. See, e.g., Seymour C. Simon, Statutory Prohibition Against the Corporate Right to Appear in Person, 14 ST. JOHN'S L. REV. 448, 450-51 (1940) (detailing the traditional rule of no corporate pro se right, but leaving open the possibility that one could exist); R. Scott Williams, Comment, A Close Look at the Rule Prohibiting a Non-Profit Corporation Pro Se Appearance, $12 \mathrm{~J}$. LEGAL PROF. 211, 212, 216 (1987) (examining the rationales of the rule prohibiting for-profit corporations from appearing pro se, noting that it is a reasonable and well thought out rule, but caution should be taken when applying it to non-profits).

${ }^{16}$ See David Millon, The Ambiguous Significance of Corporate Personhood, 2 STAN. AGorA 39, 39, 49 (2001) ("In the eyes of the law, the business corporation is a person.... [I]t enjoys various rights under the United States Constitution." Therefore "the corporate person should bear the responsibilities of a citizen."); see also Gregory A. Mark, The Personification of the Business Corporation in American Law, 54 U. CHI. L. REV. 1441, 
knowledge that corporations are legal persons and have been granted several rights that we generally only think of individuals as having. For example, corporations can be sued in civil and criminal courts, ${ }^{17}$ they can take the stand, ${ }^{18}$ they can buy and sell things, they have a Fourth Amendment right of privacy, ${ }^{19}$ and they recently have been granted First Amendment speech and religious rights. ${ }^{20}$ If corporate constitutional rights are expanding, why has the constitutional right of self-representation (both civil and criminal) not been extended to corporations? ${ }^{21}$ Why is it that corporations still cannot proceed pro se?

The rule that prohibits corporations from self-representation is over 150 years old. ${ }^{22}$ In Osborn v. Bank of the United States, the Supreme Court first articulated the rule. ${ }^{23}$ It held that "[i]t is admitted that a corporation can only appear by attorney, ... [while] [n] atural persons may appear in Court, either by themselves, or by their attorney." 24 This ruling has polluted the jurisprudence on corporate rights. Cases as recent as 1975 have used the Osborn rule and precedent to hold that corporations do not have a constitutional right to proceed pro se in criminal court and do not have a statutory right in civil court. ${ }^{25}$

1441 (1987); David Millon, Theories of the Corporation, 1990 DUKE L.J. 201, 206 [hereinafter Millon, Theories].

${ }^{17}$ See, e.g., ALA. CONST. art. XII, $\S 240$; ARIZ. CONST. art. XIV, $\S 1$; CAL. CONST. of 1849 , art. IV, § 33; N.Y. CONST. art. X, § 4; N.C. CONST. art. VIII, § 2; WASH. CONST. art. $\mathrm{XII}, \S 5$ ("[A]ll corporations shall have the right to sue and shall be subject to be sued, in all courts, in like cases as natural persons.").

${ }^{18}$ FED. R. CIV.P. 30(b)(6) ("In its notice or subpoena, a party may name as the deponent a public or private corporation, a partnership, an association, a governmental agency, or other entity and must describe with reasonable particularity the matters for examination. The named organization must then designate one or more officers, directors, or managing agents, or designate other persons who consent to testify on its behalf; and it may set out the matters on which each person designated will testify.").

${ }^{19}$ Hale v. Henkel, 201 U.S. 43, 76 (1906), overruled in part by Murphy v. Waterfront Comm'n of N.Y. Harbor, 378 U.S. 52 (1964).

${ }^{20}$ Burwell v. Hobby Lobby Stores, Inc., 573 U.S. 682, 707-08 (2014); Citizens United v. FEC, 558 U.S. 310,342 (2010); First Nat'l Bank of Bos. v. Bellotti, 435 U.S. 765, 784 (1978). For a discussion of the First Amendment rights associated with corporations, see Suneal Bedi, Fully and Barely Clothed: Case Studies in Gender and Religious Employment Discrimination in the Wake of Citizens United and Hobby Lobby, 12 Hastings Bus. L.J. 133, 183 (2016), arguing that recent expansions of First Amendment rights to corporations could create room for the legal violation of employment discrimination laws by corporations.

${ }^{21} \mathrm{My}$ focus in this article is on both the criminal and civil pro se rights. I explain the inception of both rights further below. But for the purposes of this article, all references to the "pro se right" refer both to the criminal and civil right.

${ }^{22}$ See Osborn v. Bank of U.S., 22 U.S. (9 Wheat.) 738, 830 (1824).

${ }^{23}$ Id.

${ }^{24} / d$. at 829.

${ }^{25}$ There is a long list of cases that have used Osborn's reasoning, and the following is by no means exhaustive. See, e.g., In re Las Colinas Dev. Corp., 585 F.2d 7, 13 (1st Cir. 1978); In re Victor Publishers, Inc., 545 F.2d 285, 286 (1st Cir. 1976); Simbraw, Inc. v. United States, 367 F.2d 373, 373-74 (3d Cir. 1966) (per curiam); Brandstein v. White 
The rationales for the Osborn rule fall into two separate buckets. First, courts argue that corporations cannot do anything in their own right; they must act through an agent. ${ }^{26}$ If anybody acts through an agent in a court proceeding, the agent must be a lawyer. ${ }^{27}$ As such, corporations must use lawyers in court proceedings. $^{28} \mathrm{I}$ term this the agency rationale. Second, courts argue that corporations would pervert and abuse the legal system as plaintiffs if they were given a pro se right. ${ }^{29}$ Courts argue that, unlike lawyers, business professionals are more likely to unethically use the legal system for their own interests. ${ }^{30} \mathrm{I}$ term this the public policy rationale. Both rationales, however, do not hold up under any level of scrutiny. The agency rationale is a circular argument that doesn't purport to actually answer the question at hand: Why does a corporation need an agent to represent itself? The public policy rationale is only an empirical argument, which does not hold if a corporation were defending a lawsuit.

These rationales and this form of argumentation fail to offer any guidance on how we should construe corporate pro se rights. This Article attempts to shift the discussion of corporate pro se rights from a theory of what makes individuals and corporations different to a theory of why we have pro se rights in the first instance. Once we can determine what the reason is for allowing individuals to proceed pro se, we then simply need to ask if the interests at stake in the individual context are also implicated in the corporate context. If they are, then it seems plausible to extend pro se rights to corporations.

This author could only find one court that has ever recognized a corporate pro se right. In Sellent-Repent Corp. v. Queens Borough Gas and Electricity $C o ., 31$ a New York court held that when a corporation uses a non-lawyer agent to appear in court that is part of its membership, "it is acting in person and upon an equal footing with a natural person, including the right to sue in person." 32 The court allowed a non-lawyer executive to appear on behalf of a corporation in a pro se manner. ${ }^{33}$

Lamps, Inc., 20 F. Supp. 369, 370 (S.D.N.Y. 1937); Dayton Supply \& Tool Co.v. Montgomery Cnty. Bd. of Revision, 111 Ohio St. 3d 367, 2006-Ohio-5852, 856 N.E.2d 926, at 12 , abrogated by Columbus City Sch. Dist. Bd. of Educ. v. Franklin Cty. Bd. of Revision, 134 Ohio St. 3d 529, 2012-Ohio-5680, 983 N.E.2d 1285.

26 See, e.g., Brandstein, 20 F. Supp. at 370.

${ }^{27}$ See Osborn, 22 U.S. (9 Wheat.) at 829; see also Timothy G. Cotner, May a Corporation Act as Its Own Attorney?, 16 Clev.-MARSHALL L. Rev. 173, 174 (1967).

${ }^{28}$ Cotner, supra note 27, at 174; see infra Part II.

${ }^{29}$ See Brandstein, 20 F. Supp. at 370-71 (quoting Mortg. Comm'n of N.Y. v. Great Neck Improvement Co., 295 N.Y.S. 107, 114 (N.Y. Sup. Ct. 1937); infra Part III.

${ }^{30}$ Brandstein, 20 F. Supp. at 370-71 (quoting Mortg. Comm'n of N.Y. v. Great Neck Improvement Co., 295 N.Y.S. 107, 114 (N.Y. Sup. Ct. 1937)).

31 Sellent-Repent Corp. v. Queens Borough Gas \& Elec. Co., 290 N.Y.S. 887 (N.Y. App. Div. 1936).

$32 \mathrm{Id}$. at 889 . The case is discussed further in detail below. See infra notes 123-33 and accompanying text.

${ }^{33}$ See Sellent-Repent Corp., supra note 31, at 889. 
This Article argues that, at the end of the day, the constitutional pro se right exists to protect individuals from arbitrary government action and to protect individual freedom (be it from prison, excessive fines or a deprivation of life and liberty). If protecting individuals from this deprivation is the crux of the pro se right, then corporations should also be granted the right.

I argue that litigation surrounding corporations can significantly hurt and damage the individuals that make up the corporation (not just shareholders or owners, but also lower-level employees). The damage of losing one's job, especially in a bad economy, can cause severe damage to how one is able to provide for oneself and one's family.$^{34}$ It too is a deprivation of life and liberty.

My argument here has implications for the economic theories of the firm. Corporations should be treated as simple aggregations of individuals contracting together in order to efficiently produce joint output. I draw upon economic scholarship to show that what's at stake is not the corporate entity itself, but, instead, the individual members of the corporation. Once one understands a firm as simply members producing output, the rationale for granting the pro se right to a corporation becomes clear (it protects the individuals in the firm, not necessarily the corporate entity itself).

This analysis has implications for corporate constitutional rights generally. I ultimately argue for an extension of corporate rights based upon the underlying reasons and rationales that we have for those exact constitutional rights. In addition, this Article advocates for considering corporations as aggregations of individual members when contemplating whether to extend rights of natural persons to corporate entities.

If protecting individuals from government action is of utmost importance, then it stands to reason that corporations should be able to proceed pro se because individual freedoms are at stake in a corporation just as they are in the individual context. ${ }^{35}$ Granting businesses (particularly small member-managed LLCs and partnerships) a pro se right would save these entrepreneurs time and money and allow them to more readily carry out their activities. ${ }^{36}$

The article proceeds in five parts: Part II compares and contrasts the corporate and individual pro se rights drawing upon both statutes and case law. Part III introduces and debunks the agency and public policy rationales for

${ }^{34}$ See generally Jennie E. Brand, The Far-Reaching Impact of Job Loss and Unemployment, 41 ANN. REV. OF SOC. 359 (2015) (discussing the negative consequences of job loss on a person's life).

35 Since corporations are aggregations of individuals, many economists argue that the constitutional rights of individuals should be extended to corporations as a recognition of individuals in the corporation as having those rights. See, e.g., Alan J. Meese \& Nathan B. Oman, Hobby Lobby, Corporate Law, and the Theory of the Firm: Why For-Profit Corporations are RFRA Persons, 127 HARV. L. REV. F. 273, 274 (2014) (arguing that there is "no essence of corporateness that precludes shareholders with such [religiously motivated policies] from employing for-profit corporations to exercise their religion"); see also infra Part V.

${ }^{36}$ See infra Part $\mathrm{V}$ for arguments on how lawyer fees and litigation costs hurt small businesses. 
denying corporations a pro se right. Part IV shifts the discussion to why individuals have a pro se right in the first instance. Part $\mathrm{V}$ argues that the individual interests that pro se rights protect are also implicated in the corporate context, and, hence, corporations should be able to proceed pro se. It also responds to criticisms.

\section{Corporate vs. Individual Pro Se Rights}

Over the course of the past few decades, scholars and courts have equated corporations and business organizations to people. ${ }^{37}$ In particular, they have argued that corporations, although traditionally "legal" persons, should be treated even more like natural persons. ${ }^{38}$ Initially, corporations had all the rights that we traditionally associate with a government-sponsored entity (right to sue, be sued, and buy and sell things). ${ }^{39}$ More recently, through the corporate personhood scholarship, ${ }^{40}$ corporations are being seen as having more of the rights that we associate with natural humans (the right to free speech ${ }^{41}$ and the right to practice religion ${ }^{42}$ ). The expansion of corporate rights has spurred a

${ }^{37}$ See Mark, supra note 16 , at 1441-42.

38 See Millon, Theories, supra note 16, at 203; see also Mark, supra note 16, at 1458.

${ }^{39}$ See Santa Clara Cty. v. S. Pac. R.R. Co., 118 U.S. 394, 394 (1886) (holding that the Fourteenth Amendment applies to corporations). For evidence of the disagreement of the nature of the corporation within the Court, see Trs. of Dartmouth Coll. $v$ Woodward, 17 U.S. (4 Wheat.) 518,636 (1819).

${ }^{40}$ A classic phrasing of the "corporate personhood" theory comes from Chief Justice Marshall in Dartmouth College, 17 U.S. (4 Wheat.) at 636. ("A corporation is an artificial being, invisible, intangible, and existing only in contemplation of law. Being the mere creature of law, it possesses only those properties which the charter of its creation confers upon it, either expressly, or as incidental to its very existence."). Margaret M. Blair terms this style of "corporate personhood" the "artificial person" theory and the "real entity" theory. See Margaret Blair, Corporate Personhood and the Corporate Persona, 2013 U. ILL. L. REV. 785, 799, 806 (2013) (noting that scholars regard "the corporation as a unit recognized in the law 'with its own claims, much like those of a natural person, that extend beyond both the circumstances of its legal creation by the state and the claims or interests of its shareholders"' (citing Phillip I. Blumberg, The Corporate Personality in American Law: A Summary Review, 38 AM. J. COMP. L. SUPPLEMENT 49, 50 (1990)).

41 Citizens United v. FEC, 558 U.S. 310, 342-43 (2010) (holding that a corporation had protected First Amendment political speech that was not reductive of the individuals that comprised of the corporation). Much commentary has been written on the nature of the corporation in the wake of Citizens United. See generally, e.g., Richard A. Epstein, Citizens United v. FEC: The Constitutional Right that Big Corporations Should Have but Do Not Want, 34 HARV. J.L. \& PUB. POL'Y 639 (2011); Elizabeth Pollman, Reconceiving Corporate Personhood, 2011 UTAH L. REV. 1629 (2011); David G. Yosifon, The Public Choice Problem in Corporate Law: Corporate Social Responsibility After Citizens United, 89 N.C. L. REV. 1197 (2011).

${ }^{42}$ Burwell v. Hobby Lobby Stores, Inc., 573 U.S. 682, 707-08 (2014) (holding that as a religiously based organization, Hobby Lobby qualified as a person for purposes of exempting itself from certain healthcare provisions that conflicted with its religious ideals). Again, the case has spawned much commentary both denouncing and applauding the ruling. 
large domain of scholarship that seeks to explain how substantive constitutional rights should apply to corporations. ${ }^{43}$ One area, however, that has gone largely unexplored in this domain has been procedural due process rights.

This Article is concerned with the procedural due process rights associated with the right to appear pro se in a courtroom. The Table below summarizes the pro se rights of both individuals and corporations. This Article focuses its attention on the shaded areas. It is mostly in these areas that individuals are treated differently than corporations.

Table 1: Pro Se Procedural Due Process Rights

\begin{tabular}{|c|c|c|c|c|c|c|}
\hline & \multicolumn{2}{|c|}{ Counsel Permitted } & \multicolumn{2}{c|}{ Counsel Provided } & \multicolumn{2}{c|}{ Proceed Pro Se } \\
\cline { 2 - 7 } & Corporation & Individual & Corporation & Individual & Corporation & Individual \\
\hline Criminal & $\mathrm{Y}$ & $\mathrm{Y}$ & $\mathrm{N}$ & $\mathrm{Y}$ & $\mathrm{N}$ & $\mathrm{Y}$ \\
\hline Civil & $\mathrm{Y}$ & $\mathrm{Y}$ & $\mathrm{N}$ & $\mathrm{N}$ & $\mathrm{N}$ & $\mathrm{Y}$ \\
\hline $\begin{array}{c}\text { Small } \\
\text { Claims }\end{array}$ & $\mathrm{N}$ & $\mathrm{N}$ & $\mathrm{N}$ & $\mathrm{N}$ & $\mathrm{Y}$ & $\mathrm{Y}$ \\
\hline
\end{tabular}

Reading from the top of the Table down, individuals (natural humans) have a constitutional right to appear pro se in criminal courts. ${ }^{44}$ This right is

Frederick Mark Gedicks \& Andrew Koppelman, Invisible Women: Why an Exemption for Hobby Lobby Would Violate the Establishment Clause, 67 VAND. L. REV. EN BANC 51, 66 (2014) (arguing that ruling in favor of Hobby Lobby would create a regime where significant costs of health care are going to borne by female employees). See generally, e.g., Meese \& Oman, supra note 35 (arguing that the holding in Hobby Lobby is consistent with the corporate theory of the firm).

43 See Eric W. Orts, Business Persons: A Legal Theory of The Firm 14 (2013) (arguing that corporations should be viewed with an institutional theory which holds that firms are "socially established entities that are both authorized and recognized by governments and organized and managed by individual participants"). Orts takes a more intermediary view of corporate personhood arguing that corporations are both like people in some instances and are also fictitious in other instances. See id. For an overview of arguments that claim that corporations are exactly like natural persons, see William W. Bratton, Jr., The New Economic Theory of the Firm: Critical Perspectives from History, 41 STAN. L. REV $1471,1490-91$ (1989).

${ }^{44}$ Faretta v. California, 422 U.S. 806,818 (1975). Note that individuals (unlike corporations) also have a constitutional right to receive counsel if they cannot afford one. Gideon v. Wainwright, 372 U.S. 335, 342-44 (1963); United States v. Unimex, Inc., 991 F.2d 546, 549 (9th Cir. 1993). This aspect of procedural due process is not the primary focus of this article, but the same arguments for pro se rights would apply to the right to receive counsel. The source of the differing treatment of receiving counsel is found in the Criminal Justice Act (CJA). 18 U.S.C. $\S 3006 \mathrm{~A}(\mathrm{a})(1)$ (2012). The statute lists classes of persons entitled to counsel under the Sixth Amendment and does not include corporations. See id.; 
derivative of the Fifth, Sixth, and Fourteenth Amendments to the U.S Constitution. ${ }^{45}$ For example, for criminal prosecutions, the Sixth Amendment reads, in part, "In all criminal prosecutions, the accused shall enjoy the right ... to be confronted with the witnesses against him; to have compulsory process for obtaining witnesses in his favor, and to have the Assistance of Counsel for his defence." 46 This has been interpreted over several cases to mean that individuals must be able to represent themselves in a criminal proceeding if they so choose. ${ }^{47}$ This right is well-established in the United States and has been of little controversy since its inception. Corporations, however, do not have a corollary right to proceed pro se in a criminal court. Courts have routinely held that the Sixth Amendment right of due process does not apply to corporations; instead, corporations must be represented by a lawyer in a criminal court proceeding. ${ }^{48}$ This differing treatment between individuals and corporations is an interesting phenomenon that has also bled into the civil court context. ${ }^{49}$

The federal government codified the right to appear pro se in a civil court in 28 U.S.C. $\S 1654 .^{50}$ The statute reads, in part: "In all courts of the United States the parties may plead and conduct their own cases personally ...."51 Corporations, however, do not have a right to appear pro se in a civil court ${ }^{52}$ or criminal court. ${ }^{53}$ This is because courts have explicitly interpreted 28 U.S.C. $\S 1654$ to not include corporations. ${ }^{54}$ Courts have held that the term "parties" does not include corporations. ${ }^{55}$ There is little to no rationale for why corporations are not "parties." Instead courts simply cite back to Osborn for the

Unimex, Inc., 991 F.2d at 549-50 ("If the purpose of the [CJA] is to assure that criminal defendants' constitutional right to appointed counsel is protected, then no appointments are needed for corporations. Being incorporeal, corporations cannot be imprisoned, so .... [t] $]$ he Sixth Amendment accordingly does not provide for appointment of counsel for corporations without sufficient assets to retain counsel on their own."). One supposes that the assumption is corporations are rich enough to not need counsel in any criminal proceeding.

45 See generally, U.S. CONST. amends. V, VI, XIV. The sources of the pro se right are explored in more detail below. See infra Part IV.

46 U.S. CONST. amend. VI.

${ }^{47}$ See, e.g., Faretta, 422 U.S. at 817 . The rationales and details of the individual pro se right are explored further in Part IV of this Article.

48 The rationales and details of this rule are explored in Part III of this Article.

${ }^{49}$ See, e.g., In re Victor Publishers, Inc., 545 F.2d 285, 286 (1st Cir. 1976) (per curiam) (affirming a bankruptcy court's denial of a non-lawyer's motion to appear on behalf of a corporation).

${ }^{50}$ See 28 U.S.C. $\$ 1654$ (2012).

51 Id.

52 See In re Las Colinas Dev. Corp., 585 F.2d 7, 12 (1st Cir. 1978).

53 See generally Osborn v. Bank of U.S., 22 U.S. (9 Wheat.) 738 (1824).

54 United States v. 9.19 Acres of Land, 416 F.2d 1244, 1245 (6th Cir. 1969) (per curiam) ("28 U.S.C. $§ 1654$ (1964), which provides that 'parties may plead and conduct their own cases personally or by counsel ....,' has been uniformly construed to mean that a corporation cannot appear otherwise than through an attorney.").

55 See, e.g., In re Las Colinas Dev. Corp., 585 F.2d at 12 ("The word 'parties' has been limited to individuals in an unbroken line of cases going back to at least 1840."). 
proposition that corporations cannot represent themselves. ${ }^{56}$ They provide no independent statutory interpretation of the word "parties." 57 The interpretation of 28 U.S.C. $\S 1654$ is doubly puzzling given that, in other, very similar contexts, courts have interpreted corporations as included in the definition of parties. ${ }^{58}$

There is one type of court, however, where corporations and individuals are treated identically. In small claims court, generally, no litigants are allowed to use lawyers, i.e. all litigants must represent themselves and appear pro se. ${ }^{59}$ Small claims courts are state-created courts that are geared to efficiently resolve issues that are "small," i.e. having a point of contention of less than $\$ 5,000.60$ By giving people (and corporations) a court where they cannot use lawyers, the states are protecting those litigants who are poor, unsophisticated, or unable to hire a lawyer to litigate on their behalf. ${ }^{61}$

How can a court deny the use of a lawyer to litigants when there is a constitutional right to be represented by a lawyer? Courts have determined that when states create a small claims court they are constitutionally permitted to deny the availability of lawyers as long as they preserve the right of counsel in other aspects of civil procedure. ${ }^{62}$ For example, as long as a state provides that

56 See, e.g., Greenspan v. Admin. Office of the U.S. Courts, No. 14-CV-2396 JTM, 2014 WL 6847460, at*5 (N.D. Cal. Dec. 4, 2014).

${ }^{57}$ See In re Las Colinas Dev. Corp., 585 F.2d at 12 ("We have been unable to find any case or authority intimating that the right of an individual to represent himself in the federal courts should be extended to corporations."); see also In re Victor Publishers, Inc., 545 F.2d 285, 286 (1 st Cir. 1976) (per curiam) (citing only common law tradition and practical implications to interpret "parties").

58 See infra notes 65-66 and accompanying text on the interpretation of statutes creating small claims courts.

59 See Cal. DeP'T Of CONSUMER AfFairs, The SMall Claims Court: A GuIDE to ITS PRACTICAL USE 7-8, https://www.dca.ca.gov/publications/small_claims/small_claims.pdf [https://perma.cc/5KAV-5NSQ]. California's small claims courts are codified in CAL. CIV. PROC. CODE $\S \S 116.110-116.950$. (West 2018).

${ }^{60}$ See, e.g., CAL. Civ. Proc. CODE $\S \S 116.120(a)-(b), 116.220(a)$ (West 2018). For a detailed history of small claims courts, see generally Eric H. Steele, The Historical Context of Small Claims Courts, 6 AM. B. FOUND. RES. J. 295 (1981).

61 "Justice should not be a rich man's luxury. The Manga Carta guaranteed that justice would not be denied or delayed. .. . The delay and expense incident to litigation have long discouraged the attempts of the poor litigant to secure redress for claims meritorious but small in amount." Prudential Ins. Co. v. Small Claims Court of City \& C'ty of S.F., 173 P.2d 38, 40 (Cal. Dist. Ct. App. 1946).

62 See Simon v. Lieberman, 226 N.W.2d 781, 782 (Neb. 1975) ("The parties tacitly agree that the right to appear by counsel somewhere in the proceedings must be guaranteed in order to meet the requirements of constitutional due process."); see also Prudential Ins. Co., 173 P.2d at 39-40 ("There can be little doubt but that in both civil and criminal cases the right to a hearing includes the right to appear by counsel, and that the arbitrary refusal of such right constitutes a deprivation of due process. But that does not mean that the legislature cannot create a Small Claims Court where informat hearings may be held without the assistance of counsel, as long as the right to appear by counsel is guaranteed in a real sense somewhere in the proceeding." (citation omitted)). 
appeals from small claims court (appeals would generally go to a state trial court) carry with them a right to be represented by counsel, individuals' constitutional rights are sufficiently protected. ${ }^{63}$

Two things are interesting to note about the pro se requirement of small claims court. The first is the language of statutes that create such courts. The California Code of Civil Procedure $\S 116.530$ (a) reads in part: " $[N]$ o attorney may take part in the conduct or defense of a small claims action." here (unlike in 28 U.S.C. $\S 1654$ ) are deemed to be "persons" for purposes of the small claims court. ${ }^{65}$ In effect, corporations are seen as individuals in small claims court. They don't just have the same rights as a natural person, but they are actually deemed to be natural persons for purposes of these courts. To hold otherwise would "deprive corporations of the opportunity to appear and defend such actions, since the artificial entity cannot itself speak, and this would deprive corporations of due process." 66 This begs the question why, in certain circumstances (civil and criminal courts), corporations are not treated like individuals, but they are treated like individuals in other circumstances when the language of the relevant statutes is very similar.

Second, when a corporation appears in a small claims court, it truly is seen as representing itself. 67 One could argue that when a corporation appears pro se in small claims court, it is simply the court permitting some non-lawyer person that is part of the company to represent the interests of the corporation in the same way a lawyer does. If this were the case then it would seem that small claims courts still wouldn't recognize a corporate pro se right but instead recognize the ability of a non-lawyer to represent a corporation. This, however, is not how a corporation is viewed in these courts. ${ }^{68}$ Instead, the court treats the corporation just like it treats the natural person. ${ }^{69}$ Therefore, the corporation is not being represented by a non-lawyer, instead it is truly representing itself and appearing in its own capacity as a corporation. ${ }^{70}$ Another way to think of this

${ }^{63}$ See Simon, 226 N.W.2d at 783 ("The Idaho Supreme Court has also held that where a defendant on appeal from the small claims court to the District Court may avail himself of a right to obtain a trial de novo with assistance of counsel therein, the requirement of due process is satisfied, and a statute permitting such small claims court proceedings is not unconstitutional ....").

${ }^{64}$ CAL. CiV. Proc. CODE $\$ 116.530$ (a) (West 2018). However, an attorney may appear if she is representing herself or a partnership/professional corporation where she and all the other partners/directors are attorneys. Id. $\$ 116.530(\mathrm{a})$, (b)(1)-(3).

${ }^{65}$ See id. $\$ 116.130$; Prudential Ins. Co., 173 P.2d at 41 ("[T] he word 'person' includes a corporation as well as a natural person." (citation omitted)).

66 Prudential Ins. Co., 173 P.2d at 41.

${ }^{67}$ See id. at $41-42$.

${ }^{68} \mathrm{See}$ id. at 42. (arguing against the conclusion that "a corporation under no circumstances may appear in a court of law in propria persona").

${ }^{69}$ See id. at 41.

${ }^{70}$ See id. at $41-42$ (noting that the natural person to which a corporation appears in a small claims is not an "other person," instead it is a natural person who is the corporation for the relevant claim). "Thus, here, unlike the above cases, there is express statutory 
distinction is that when a corporation appears in a small claims court, the court does not treat the situation as if the CEO is appearing on behalf of Widget LLC, instead, the court views the representation as Widget LLC appearing on behalf of itself.

Before proceeding to the rationales for denying corporations both a civil and criminal pro se right, it's worth pointing out here the different legal sources of the pro se right in state versus federal courts. The Table below summarizes these sources:

Table 2: Legal Sources of the Pro Se Right

\begin{tabular}{|l|c|c|}
\hline State & Civil & Criminal \\
\hline Federal & $\begin{array}{c}\text { Fifth and Fourteenth } \\
\text { Amendments } \\
\text { (State Constitutions) }\end{array}$ & $\begin{array}{c}\text { Sixth and Fourteenth } \\
\text { Amendments (State } \\
\text { Constitutions) }\end{array}$ \\
\hline
\end{tabular}

As will be further shown in detail below, state pro se rights most generally come from specific state constitutions. ${ }^{71}$ Most states have guaranteed both a civil and criminal pro se right for individuals. ${ }^{72}$ These rights in the civil context arise out of traditional due process rights (the Fifth and Fourteenth Amendments). ${ }^{73}$ State criminal pro se rights arise out of the federal criminal pro

authorization for a corporation to appear in propria persona through some proper representative ...." Id. at 42 .

71 See JONA GOLDSCHMIDT, BARRY MAHONEY, HARVEY SOLOMON \& JOAN GREEN, MeEting THE ChaLLENGE OF Pro SE Litigation 22-23 (1998).

72 See id. at $130-34$ (listing state statutes and constitutional provisions providing the right to self-representation). The following are some examples of state language protecting both a civil and criminal pro se right: ALA. CONST. art. $1, \S 10$ ("That no person shall be barred from prosecuting or defending before any tribunal in this state, by himself or counsel, any civil cause to which he is a party."); GA. CONST. art. I, $\S 1$, para. XII ("No person shall be deprived of the right to prosecute or defend, either in person or by an attorney, that person's own cause in any of the courts of this state."); and DEL. JUDGES' CODE OF JUDICIAL CONDUCT R. 2.6(A) ("A judge should accord to every person who is legally interested in a proceeding, or to the person's lawyer, full right to be heard according to law.").

${ }^{73}$ See Hudson v. Palmer, 468 U.S. 517, 523 (1984) ("Like others, prisoners have the constitutional right to petition the Government for redress of their grievances, which includes a reasonable right of access to the courts."); see also Jackson v. Procunier, 789 F.2d 307, 311 (5th Cir. 1986) (holding that all parties have a right to access of the courts in civil proceedings). Although these cases are not directly related to self-representation, the civil pro se right has been thought to stem from the right of access to courts. See GOLDSCHMIDT ET AL., supra note 71, at 21,24; Julie M. Bradlow, Comment, Procedural Due Process Rights of Pro Se Civil Litigants, 55 U. CHI. L. REV. 659, 677-78 (1988). Moreover, for practical purposes, basically all states have guaranteed a civil pro se right via their respective constitutions. See GOLDSCHMIDT ET AL., supra note 71, at 130-34. 
se right recognized by the Sixth Amendment and incorporated by the Fourteenth. ${ }^{74}$ When discussing pro se rights, this Article refers to all four cells in the table above. It argues that corporations should have state and federal and criminal and civil pro se rights. ${ }^{75}$

\section{Rationales for Denying CoRporations Pro Se Rights}

\section{A. The Agency'Rationale}

In 1824, the Supreme Court announced the rule that corporations could not represent themselves in Osborn v. Bank of United States. ${ }^{76}$ The case concerned the State of Ohio taxing the Bank of the United States. ${ }^{77}$ Ohio enacted a statute that levied a tax on the Bank. ${ }^{78}$ The Bank refused to pay the tax, and the state auditor forcibly removed the monies from the Bank. ${ }^{79}$ The Bank then sued the State of Ohio to return the funds. ${ }^{80}$ The lower court ruled in favor of the Bank, and the Supreme Court affirmed the lower court's ruling as to returning the monies. ${ }^{81}$

In determining that the Bank was due its return of money seized, Chief Justice Marshall made two key holdings. The first concerned the constitutional right of the Bank to sue in federal court. ${ }^{82}$ The Court held that "the clause in the act of incorporation, enabling the Bank to sue in the Courts of the United States, is consistent with the constitution...."83 Marshall argued that the Bank's charter was to be treated in the same manner as the "acts authorizing officers of the United States who sue in their own names, to sue in the Courts of the United States." 84

The second (and relevant for the argument here) holding set the stage for the next 197 years. ${ }^{85}$ After determining the constitutionality of the Bank to sue in federal court, Marshall held that corporations could not represent themselves in court. ${ }^{86}$ The issue in the case was whether the Bank had granted authority to an individual for it to be represented in court. ${ }^{87}$ The State of Ohio argued that no person could represent the Bank because there was no authorization in the

\footnotetext{
${ }^{74}$ Faretta v. California, 422 U.S. 806, 813, 818-19 (1975).

${ }^{75}$ For state civil pro se rights, they should have the same rights that individuals have.

7622 U.S. (9 Wheat.) 738,830 (1824).

77 Id. at $739-40$.

${ }^{78} \mathrm{Id}$. at 740 .

79 Id. at 741

$80 \mathrm{Id}$. at 742

$81 \mathrm{Id}$. at $870-71$.

82 See Osborn, 22 U.S. (9 Wheat.) at 818.

83 ld. at 828.

$84 \mathrm{Id}$. at 825 .

${ }^{85}$ Osborn was decided in 1824 and remains good law. See generally id. (lacking any direct negative treatment).

86 See id. at 830 .

87 Id. at 828 .
} 
Bank's constitution. ${ }^{88}$ Marshall held, however, that: "It is admitted that a corporation can only appear by attorney, and it is also admitted, that the attorney must receive the authority of the corporation to enable him to represent it." 89

But this authorization need not be "under seal" and need not be elucidated in the constitution - instead, the "seal may be dispensed with. ${ }^{" 90}$ But this wasn't the prime issue. ${ }^{91}$ The State of Ohio argued that, since no lawyer was authorized, the Bank had attempted to represent itself in the court proceedings. ${ }^{92}$

Marshall began by articulating the old rule that natural persons can represent themselves in court. ${ }^{93}$ In particular, he noted that "[n]atural persons may appear in Court, either by themselves or by their attorney." 94 He then went on to articulate that no person has a right to appear on behalf of another person unless that person is (1) authorized by the litigant, and (2) authorized by the court (i.e. is a lawyer) ${ }^{95}$ Corporations however need a person to appear on their behalf in court. ${ }^{96}$ Since any person that appears on behalf of another must be a lawyer, corporations must only be represented by lawyers. ${ }^{97}$

I term this original rationale for disallowing corporations a pro se right the agency rationale. Effectively, the Osborn Court's rationale goes like this: since corporations cannot accomplish tasks in their own right (i.e. they always need a natural person who is an agent) when appearing in court, they obviously need a natural person or agent to represent their interests. Therefore, since only lawyers can be agents in a court, corporations must be represented by lawyers. ${ }^{98}$

Several cases and courts have upheld this rationale in one way or another. In Brandstein v. White Lamps, Inc., the court held that although it's clear that "parties may plead and manage their own causes personally," 99 corporations are not traditional parties. ${ }^{100}$ Corporations are only legal entities and legal fictions,

88 See Osborn, 22 U.S. (9 Wheat.) at 745.

$89 \mathrm{Id}$. at 829.

${ }^{90} \mathrm{Id}$.

91 See id.

$92 \mathrm{Id}$. at 746.

93 See id. at 829.

94 Osborn, 22 U.S. (9 Wheat.) at 829.

95 Id. ("But no man has a right to appear as the attorney of another, without the authority of that other. In ordinary cases, the authority must be produced, because there is, in the nature of things, no prima facie evidence that one man is in fact the attorney of another.").

$96 \mathrm{Id}$. at 829-30.

97 See id. at $829-30$.

98 Other scholars have phrased the rationale in a similar way. See, e.g., Cotner, supra note 27 , at 174 ("[C]orporations can only be represented and can only act through agents; a corporation cannot represent itself, therefore it must appear in court through the person of a duly qualified attorney.").

9920 F. Supp. 369,370 (S.D.N.Y. 1937) (quoting 28 U.S.C.A. $\$ 394$ (current version at 28 U.S.C. $\$ 1654(2018))$ ).

${ }^{100}$ See id. (noting a "corporation [can] not plead and manage its case personally" (quoting Mullin-Johnson Co. v. Penn Mut. Life Ins. Co., 9 F. Supp. 175, 175 (N.D. Cal. 1934)). 
and, as such, they only exist in the law and cannot act in their own rightcan only act through agents. ${ }^{101}$

In Simbraw, Inc. v. United States, a corporation appealed to the Third Circuit to allow it to represent itself by sending the corporation's president to court. ${ }^{102}$ The court there, relying upon Osborn, held that "[t]he rule is well established that a corporation can appear in a court of record only by an attorney at law." 103 Later, the Fifth Circuit came to a similar ruling, even though the corporation at issue had only one shareholder. ${ }^{104}$ In that case, the sole shareholder attempted to argue that K.M.A., Inc. should be able to appear pro se. ${ }^{105}$ After all, all the relevant interests in the corporation were present via the sole shareholder. ${ }^{106}$ This argument fell on deaf ears, and the court, utilizing the Osborn rationale, ruled that the corporation may not represent itself and must use a lawyer. ${ }^{107}$ These two cases only represent a few of several that have held in favor of the prohibition on corporate pro se litigants. ${ }^{108}$

${ }^{101} I d$. ("Since a corporation can appear only through its agents, they must be acceptable to the court; attorneys at law, who have been admitted to practice, are officers of the court and subject to its control.").

102367 F.2d 373, 373 (3d Cir. 1966) (per curiam).

103 Id. at 374 (quoting Flora Constr. Co. v. Fireman's Fund Ins. Co., 307 F.2d 413, 414 (10th Cir. 1962)).

104 K.M.A., Inc. v. Gen. Motors Acceptance Corp. (In re K.M.A., Inc.), 652 F.2d 398, 399 (5th Cir. Unit B July 1981).

105 Id.

${ }^{106}$ See Tiffany C. Wright, What Is the Difference Between a Shareholder and Ownership Interest in Corporation?, AZCENTRAL, https://yourbusiness.azcentral.com/differencebetween-shareholder-ownership-interest-corporation-24705.html [https://perma.cc/M4PKX7TW] (last updated Apr. 13, 2018).

107 In re K.M.A., Inc., 652 F.2d at 399 ("The law is clear that a corporation as a fictional legal person can only be represented by licensed counsel. This is so even when the person seeking to represent the corporation is its president and major stockholder." (internal citations omitted)).

108 For other cases with the same agency rationale, see Commercial \& R.R. Bank v. Slocomb, Richards \& Co., 39 U.S. (14 Pet.) 60, 65 (1840), overruled in part by Louisville, C.\&C.R. Co. v. Letson, 43 U.S. (2 How.) 497 (1844); In re Las Colinas Dev. Corp., 585 F.2d 7, 13 (1st Cir. 1978); In re Victor Publishers, Inc., 545 F.2d 285, 286 (1st Cir. 1976); United States v. 9.19 Acres of Land, 416 F.2d 1244, 1245 (6th Cir. 1969) (per curiam); Shapiro, Bernstein \& Co. v. Cont'l Record Co., 386 F.2d 426, 427 (2d Cir. 1967) (per curiam); Flora Constr. Co. v. Fireman's Fund Ins. Co., 307 F.2d 413, 414 (10th Cir. 1962); Acme Poultry Corp. v. United States, 146 F.2d 738, 740 (4th Cir. 1944); James v. Daley \& Lewis, 406 F. Supp. 645, 648 (D. Del. 1976); Turner v. Am. Bar Ass'n, 407 F. Supp. 451, 476 (N.D. Tex. 1975), aff'd sub nom., Taylor v. Montgomery, 539 F.2d 715 (7th Cir. 1976), and Pilla v. Am. Bar Ass'n, 542 F.2d 56 (8th Cir. 1976); MacNeil v. Hearst Corp., 160 F. Supp. 157, 159 (D. Del. 1958); Brandstein v. White Lamps, Inc., 20 F. Supp. 369, 370 (S.D.N.Y. 1937); Nightingale v. Or. Cent. Ry. Co., 18 F. Cas. 239, 240 (C.C.D. Or. 1873); and Clark v. Austin, 101 S.W.2d 977, 982-83 (Mo. 1937). 
Although the agency rationale is very robustly used for the proposition that corporations may not represent themselves, ${ }^{109}$ under any modicum of scrutiny, the rationale's weaknesses are revealed. First, the rationale is a circular argument that doesn't purport to answer the question "why can't corporations represent themselves?" To see why, it helps to lay out the premises of the argument clearly:

1. If an individual chooses to be represented in a court by another person (an agent), that person must be a lawyer.

2. Corporations must act through another person (an agent) at all times.

3. A corporation needs an agent in order to appear or make arguments in a court room, because of Premise 2 .

4. Taking Premises 1-3 as true, it must be the case then that a corporation be represented by a lawyer in a courtroom.

On an initial read, this reasoning might make sense. However, Premise 3 assumes the conclusion that corporations may not represent themselves in court. If the main premise of the Osborn rule is that corporations can only be represented by an agent, then the rationale answers its own question. After seeing the above argument, the skeptical reader is still left with the question of, "Why is it that a corporation needs an agent to represent itself in the court room?" The result then is that the agency rationale assumes that corporations may only appear through agents and so they must appear with an attorney. ${ }^{110}$ It does not, however, provide an independent rationale for why corporations need to be represented by an agent. ${ }^{111}$

One could point to Premise 2 for proof that corporations need an agent in a courtroom. Corporations are artificial entities, and they can't do anything in real life because they are just words on a piece of paper (or a license given by a state's treasurer). ${ }^{112}$ If a corporation is to do anything, it must do it through an agent (a natural person). In that way, corporations cannot be lawyers for themselves, because only natural persons can do things in a courtroom. ${ }^{113}$

Again, if we probe the reasoning of Premise 2, we find weaknesses. As a matter of physics, yes, corporations need natural people to take action. However,

109 See, e.g., Clark, 101 S.W.2d at 983 (laying out the agency rationale and concluding that "a corporation cannot appear in propria persona").

110 See Cotner, supra note 27 , at 174 ("[C]orporations can only be represented and can only act through agents; a corporation cannot represent itself, therefore it must appear in court through the person of a duly qualified attorney. This does follow logic, but what seems to be missing at this point is the real, compelling answer to the question-Why? Why cannot a corporation appear through the agency of one who is not an attorney?").

111 Id.

112 Clark, 101 S.W.2d at 982 ("A corporation is not a natural person. It is an artificial entity created by law. Being an artificial entity it cannot appear or act in person. It must act in all its affairs through agents or representatives.").

113 See, e.g., Brandstein, 20 F. Supp. at 370. 
law has never been about pure physics. ${ }^{114}$ Although the corporation cannot physically take action and must rely on its members to do so, we routinely impute actions of natural people onto the corporation as a whole. We do not doctrinally and logically think that a natural person is acting on behalf of the corporation, we think the corporation is doing the action. ${ }^{115}$ Take, for example, the simple example of buying a computer from the Apple Store. When someone asks us, "Where did you get that computer from?" one is hard pressed to imagine someone saying, "I bought it from Suzie in a blue shirt who works for Apple and is acting as an agent for Apple." The sheer ridiculousness of such an answer should be proof enough that doctrinally, this is not how we as consumers think. Instead, generally, we act as if we bought the computer from Apple, the corporation. When we speak of the product (its pros and cons) we impute all of this to the corporation's actions, as if the corporation is acting within its own right. ${ }^{116}$

One might respond that this is simply a matter of efficient language. That we can't go around explaining corporate action in terms of the natural people who do those actions, so it's only a matter of efficiency that we impute the actions of individuals to corporations. However, thinking of corporations doing things in their own right is not just a product of efficient speech. Take other constitutional rights associated with corporations. Corporations have a First Amendment right to give money to political campaigns. ${ }^{117}$ This right accrues to the corporation as an entity and is exercised by the corporation in its own right. ${ }^{118}$ Our judicial system allows corporations to be sued and to sue in their own right. ${ }^{119}$ It allows them to be responsible for the actions that they take, while the natural people who do the actions are not held liable in many instances. ${ }^{120}$

${ }^{114}$ For an example of the U.S. Supreme Court's willingness to subvert science in their analysis, see Nix v. Hedden, 149 U.S. 304, 307 (1893) (classifying a tomato as a vegetable even though botanically speaking they are "the fruit of a vine").

115 Deborah A. DeMott, When Is a Principal Charged with an Agent's Knowledge?, 13 DUKE J. COMP. \& INT'L L. 291, 292-93 (2003).

116 This example works for any real action by a corporation. One would not say that Coca Cola's CEO and board of directors signed a document that constituted a transaction where the shareholders of Coke now own shares of Pepsi. Instead, we would simply say that Coke bought Pepsi. In common language we impute the actions of several people onto the corporation as if the corporation acted on its own behalf. See id.

117 Citizens United v. FEC, 558 U.S. 310,342 (2010).

118 See Carnell Constr. Corp. v. Danville Redevelopment \& Hous. Auth., 745 F.3d 703, 710 (4th Cir. 2014) (noting that corporations even though artificial might even be able to have a designated race).

119 See id. at 714.

120 See James R. Elkins, Corporations and the Criminal Law: An Uneasy Alliance, 65 KY. L.J. 73, 78-85 (1976); Brent Fisse, Reconstructing Corporate Criminal Law: Deterrence, Retribution, Fault, and Sanctions, 56 S. CAL. L. REV. 1141, 1148 (1983); Developments in the Law, Corporate Crime: Regulating Corporate Behavior Through Criminal Sanctions, 92 HARV. L. REV. 1227, 1230 (1979). For an extensive discussion of how individual acts lead to liability of the corporation as a whole, see generally CORPORATIONS AS CRIMINALS (Ellen Hochstedler ed., 1984) (arguing that in some instances 
We even put corporations on the stand in civil and criminal proceedings. ${ }^{121}$ It is of no debate that the corporation, on paper, cannot take the stand. However, when a natural person appears as a Rule $30(\mathrm{~b})(6)$ witness, we treat that individual as if the corporation is representing itself on the stand. ${ }^{122}$ The reality is that we treat actions that are supposed to be corporate in nature as such. We not only semantically, but also legally and doctrinally, believe that corporations do things in their own right. We even sometimes allow them to do things in their own right in a courtroom.

One court has adopted this more expansive view of corporate pro se rights. In Sellent-Repent Corp. v. Queens Borough Gas \& Electric Co., a New York court held that a corporation could represent itself. ${ }^{123}$ In holding that the corporation could appear pro se, the court articulated that there is a "distinction between a corporate act performed by a person employed to act as its agent and attorney and a like act done by the corporation through its own administrative officers." 124

The Sellent court recognized that when an agent acts on behalf of the corporation, in effect the corporation is taking action itself through the representative agent; "the act of the corporate officer in employing an agent is the act of the corporation." 25 The officers of a corporation are the "vehicle . . by and through which [the corporation] is given being." 126

However, when a lawyer represents a corporation, the lawyer isn't taking action as the corporation itself. ${ }^{127}$ There is a difference between "acting for oneself by an inherent faculty and the employment of another person to act for and in one's stead." 128 The employee agent of a corporation, when acting in normal business capacities, is not like the lawyer agent. ${ }^{129}$ The lawyer agent does not represent an action of "inherent faculty." 130 Instead, when a corporation uses an agent that is part of its membership in court, it "is acting in person and upon an equal footing with a natural person, including the right to sue in person."131

holding the corporation, rather than individuals, responsible is an acceptable solution); NEW DEVELOPMENTS AND PERSPECTIVES ON CORPORATE CRIME LAW ENFORCEMENT IN AMERICA (Leonard Orland \& Harold R. Tyler eds., 1987) (discussing corporate criminal liability generally); and Kathleen F. Brickey, Corporate Criminal Liability 41 BuS. LAW. 1107 (1986) (discussing vicarious liability).

121 See Brazos River Auth. v. GE Ionics, Inc., 469 F.3d 416, 434 (5th Cir. 2006).

122 See FED. R. CIV. P. 30(b)(6).

123290 N.Y.S. 887,889 (N.Y. App. Div. 1936).

124 Id.

$125 / d$.

$126 / d$

127 See id.

128 Id.

129 Sellent-Repent Corp., 290 N.Y.S. at 889.

${ }^{130}$ Id.

131 ld. 
If the above isn't convincing, think simply of small claims court. As described above, corporations are allowed to proceed pro se in small claims courts. ${ }^{132}$ As a matter of fact, they are denied representation by an attorney in those courts. If it's truly impossible for a corporation to physically represent itself, then how does it do so in small claims court? The answer is that the courts allow it. The law conceptually can and does accommodate a corporate pro se right in some circumstances. If it can accommodate a right in one court, why is the agency rationale only applicable in civil and criminal courts? If courts truly believe the agency rationale, then they should also prohibit corporations from appearing pro se in small claims courts because, by their own reasoning, an agent of the corporation is going to represent it, and only lawyers can be agents in a courtroom. ${ }^{133}$ The agency rational fails because we allow corporations to do things in their own right all the time. ${ }^{134}$

Therefore, after thinking about the agency rationale, one still is longing to know, "[w]hy cannot a corporation appear through the agency of one who is not an attorney?"135

132 See generally supra Part II (describing how corporations and individuals are treated identically in small claims courts).

133 Sellent-Repent Corp., 290 N.Y.S. at 889.

${ }^{134}$ For some, this argument might not be sufficient. One might argue that, metaphysically, corporations must act through agents as opposed to in their own right. For a response to this critique (although not one the court has made), one can look to group agency theory. This theory posits that although individuals act in order to take corporate action, no one person takes the exact action that the corporation is said to have performed. For example, when buying a company, although the final contract that purchases the company is signed by some executive officer, she has not actually bought the company. That is, the individual actions that lead to a company acquiring another company do not simply aggregate in the acquisition result. Instead, there is some identified action that a corporate entity has taken that is not attributable to each member of the corporation. For such arguments, see generally Christian List \& Phillip PeTtit, Group AgenCy: The Possibility, Design, and Status OF CORPORATE AGENTS (2011) (discussing realist and eliminativist views of group theory), and Margaret Gilbert, Corporate Misbehavior and Collective Values, 70 BROOK. L. REV. 1639 (2005) (discussing group beliefs and values). Note that this argument would implicate the arguments made by many corporate personhood scholars. These scholars argue that corporations should be seen as entities distinct from their members. In particular, they should be treated like natural persons, not just aggregations of their members' interests.

The real entity paradigm implied that corporations owe their existence and legitimacy to the distinct and unified purposes and wills of groups. Because group purposes and wills were unified and distinct from those of individual members, the existence of a corporate entity was deemed to be as real as the existence of its members.

Mark M. Hager, Essay, Bodies Politic: The Progressive History of Organizational "Real Entity" Theory, 50 U. PITT. L. REV. 575, 580 (1989); see also Morton J. Horwitz, Santa Clara Revisited: The Development of Corporate Theory, 88 W. VA. L. REV. 173, 185 (1985).

135 Cotner, supra note 27, at 174. 


\section{B. The Public Policy Rationale}

While not articulated in the Osborn decision, courts have employed another rationale for denying corporations a pro se right. Although these rationales are formulated in different ways, I will label all of them, collectively, the "public policy rationale." I use public policy here to distinguish other rationale from a doctrinal rationale. The public policy rationale draws upon the ramifications that allowing corporations a pro se right might have. ${ }^{136}$

In Brandstein, the court articulated potential negative externalities if corporations were allowed to represent themselves:

Were it possible for corporations to prosecute or defend actions in person, through their own offices, men unfit by character and training, men, whose credo is that the end justifies the means, disbarred lawyer or lawyers of other jurisdictions would soon create opportunities for themselves as officers of certain classes of corporations and then freely appear in our courts as a matter of pure business not subject to the ethics of our profession or the supervision of our bar associations and the discipline of our courts. ${ }^{137}$

This rationale might be seen as two separate things. The first is the law lobby protecting the monopoly it has on the legal arena. ${ }^{138}$ That is to say, the court might be saying that it just doesn't want lawyers to become unemployed if all corporations were going to stop using lawyers to represent themselves. The second is that the court is arguing that business people, who will naturally be the people that will appear in court, are "unfit by character" and are of a mentality that "the end justifies the means." 139 The court here is basically saying that it doesn't trust that business people can ethically manage cases, and it is assuming that all business people are, by their very nature, evil to some degree. ${ }^{140}$

$136 \mathrm{Id}$. at $177-78$.

${ }^{137}$ Brandstein v. White Lamps, Inc., 20 F. Supp. 369, 370-71 (S.D.N.Y. 1937) (quoting Mortg. Comm'n of N.Y. v. Great Neck Improvement Co., 295 N.Y.S. 107, 114 (N.Y. Sup. Ct. 1937)).

${ }^{138}$ Other courts have employed similar arguments saying that a court will lose control over the members representing the corporation, emphasizing the necessity of control over a judicial proceeding. See Mercu-Ray Indus., Inc. v. Bristol-Myers Co., 392 F. Supp. 16, 20 (S.D.N.Y. 1974), aff'd, 508 F.2d 837 (2d Cir. 1974); MacNeil v Hearst Corp., 160 F. Supp. 157, 159 (D. Del. 1958); People ex rel. Andrews v Hassakis, 129 N.E.2d 9, 11 (III. 1955); see also Cotner, supra note 27, at 175; Williams, supra note 15, at 212.

${ }^{139}$ Brandstein, 20 F. Supp. at 370-71 (quoting Mortg. Comm'n of N.Y. v. Great Neck Improvement Co., 295 N.Y.S. 107, 114 (N.Y. Sup. Ct. 1937)).

${ }^{140}$ For a similar argument, see Editorial Notes, Appearance of Corporation Without Attorney, 7 BROOK. L. REV. 371, 375-76 (1938) ("[T] allow the corporation to appear by an agent and say that it is appearing in person would give it an uncalled-for advantage over the individual. ... [ $t$ ] he extensive field of corporate litigation would be opened to anybody whether or not admitted to the bar."), and Jay M. Zittner, Annotation, Propriety and Effect 
There are two responses that one can make to the public policy rationale. The issue with most of the reasoning of the court is that it relies only upon empirical claims that may or may not be true. First of all, most corporations might, and probably still will, use lawyers to litigate cases and will certainly use lawyers still for transactions outside the courtroom. One could even argue that as soon as a few corporations attempt to represent themselves and lose badly, all corporations will be scared into using lawyers all the time. These are just as plausible stories as the court's. In particular, the court gives us no reason to believe its empirical claim as opposed to other claims.

The court also makes an empirical claim as to the character of business people. ${ }^{141}$ It argues that business people are generally corrupt and will corrupt the legal system if they are allowed to partake in it. ${ }^{142}$ Again, there are no grounds for assuming that, on average, business people are bad by nature. Although, to be a business person one need not take an ethics exam, like a lawyer, ${ }^{143}$ this is not at all reasonable proof that business people are corrupt on aggregate. It's shocking that a court could make such a bold claim about a large portion of the labor supply without any kind of empirical, or even, logical support.

The second response one might have is that the reasons the court gives here are also true for individuals. Individuals can also pervert the court system by being unethical and promoting ends over means. ${ }^{144}$ They can also put lawyers out of a job by always representing themselves. ${ }^{145}$ If every criminal defendant decided to represent themselves, then all public defenders and private defense attorneys would be out of jobs. But one can assume a world that didn't allow natural persons to appear pro se. If a court were to say this about extending the right to appear pro se to natural persons, there would be severe backlash. First, people would argue that the empirical claims are unsound and not based upon any reasonable proof. And second, arguably most importantly, people (and parties) have a constitutional right to represent themselves. ${ }^{146}$ Taking that right away is not appropriate. Under this reasoning, it's clear, like the agency rationale, the public policy rationale fails to answer the exact question it purports to respond to. That is, why is it that corporations are not due a fundamental right to proceed pro se, like an individual? If letting a natural person appear pro se has several negative externalities, ${ }^{147}$ but we as a country still value it, ${ }^{148}$ why do

of Corporation's Appearance Pro Se Through Agent who Is Not Attorney, 8 A.L.R. 5th 653, $\S 3[a](1992)$.

141 Brandstein, $20 \mathrm{~F}$. Supp. at $370-71$.

142 Id.

$143 / d$.

$144 / d$. at 370.

145 See id. at $370-71$.

146 Faretta v. California, 422 U.S. 806, 818-19 (1975).

147 See generally Jennifer E. Ihlo \& John Hinton III, The Pro Se Defendant, 46 U.S. ATTY'S BULL. 29 (1998) (highlighting the potential consequences of appearing pro se). 148 Id. at 29. 
we not value a corporation's right to represent itself pro se in the same way even in the face of potential negative externalities? The public policy rationale just doesn't get us to why corporations might or might not fundamentally and doctrinally have a right to represent themselves.

Other courts have posited similar rationales that read slightly differently. One court argued that corporations, if allowed to proceed pro se, would harass natural persons and create an abundance of frivolous lawsuits. ${ }^{149}$ As one legal scholar put it: "[U]nfortunate defendants might be subject to the severe harassment of groundless, malicious suits by a corporate plaintiff whose litigation agents were not bound by the ethical restraints placed on the legal profession ...." 150 Again, this is an empirical claim, but it's also one that doesn't hold up in all circumstances. If courts are truly worried about plaintiff corporations suing individuals, then why not just limit the corporate pro se right to defendant corporations? ${ }^{151}$ This would solve the harassment and frivolous lawsuit problem.

Finally, opponents of the corporate pro se right should recognize that there is a venue that has tested granting pro se right to corporations. In small claims court, corporate entities are allowed to represent themselves and appear without lawyers. ${ }^{152}$ Executives or other employees are allowed to represent the corporation. ${ }^{153}$ There has been no trouble, at least up to this point, with allowing business men and women to appear in a court proceeding. From the only empirical evidence available, the opposite conclusion should be drawn: business people will not pervert the legal system if extended pro se rights.

\section{Rationales For the Pro Se Right}

The above discussion focused on how the right to appear pro se might or might not apply to corporation actions (i.e. if corporations can represent themselves in court). The agency and public policy rationales start at the corporate level and attempt to distinguish how corporations are not like natural persons in a courtroom. In effect, the classic rationales described above attempt to apply their own theories of the firm to the pro se constitutional right. They attempt to show how a certain conception of the firm lends itself to denying firms pro se rights. This general move to start with a theory of the firm is misguided, not just because the rationales are weak.

The classical proponents of the agency and public policy rationales fail to focus on why the pro se right exists in the first instance. I argue that instead of focusing on theories of the firm, a more fruitful understanding of the corporate

149 See Brandstein, 20 F. Supp. 369, 370-71.

${ }^{150}$ Comment, Appointment of Counsel for a Defaulting Corporation in a Criminal Proceeding, 1960 DUKE L.J. 649, 651 (1960).

$151 \mathrm{Id}$. at 652 .

152 See, e.g., Cleveland Bar Ass'n. v. Pearlman, 106 Ohio St. 3d 136, 2005-Ohio-4107, 832 N.E.2d 1193, at ๆๆ 26-28.

153 Babe Houser Motor Co. v. Tetreault, 14 P.3d 1149, 1153 (Kan. 2000). 
pro se right must start with the question of why we even have pro se rights in the first place. Once we understand why pro se rights exist for natural persons in a corporate-free world, we then, simply, need to ask if the rationales for pro se rights apply in the corporate context.

In this section, I argue that the underlying rationale for the pro se right is to protect natural people from the potential harmful effects of the judicial system. By giving natural people a pro se right, we as a society are attempting to provide the individual with every possible safeguard against putting them in jail, prohibitively fining them, and ultimately hurting them by depriving them of life and liberty. In the following section, I show that protecting people is an equally important consideration in the corporate context. In that way, if protecting people is what the pro se right is about, it should apply equally to corporations, because corporations are by their nature associations of natural persons.

\section{A. The Magna Carta and the Original Founders}

The pro se right is a type of procedural due process right that is granted to individuals in the United States. ${ }^{154}$ Other procedural due process rights include the right to a jury trial, the right to hire an attorney, and the right to a speedy trial. ${ }^{155}$

The first instance of procedural due process rights arose from the Magna Carta. ${ }^{156}$ In its first iteration in June of 1215 , the Magna Carta was a peace treaty designed by the Archbishop of Canterbury to appease the group of rebels against King John of England. ${ }^{157}$ King John generally ruled by the principle of vis et voluntas. ${ }^{158}$ This "force and will" type of rule allowed King John to, often arbitrarily and forcefully, take property from non-royal subjects and imprison the same subjects whenever he pleased. ${ }^{159}$ Barons under King John rejected this type of rule and demanded safeguards against the King's arbitrary rulings and actions. ${ }^{160}$ This attempt to create peace was the foundation of the Magna

154 See James D. Hurley, Notes \& Comments, The Right to Defend Pro Se-Faretta v. California: Due Process and Beyond, 11 TulsA L.J. 365, 368 (1976).

155 For an extensive discussion of procedural due process rights, see generally Peter $\mathbf{J}$. Rubin, Square Pegs and Round Holes: Substantive Due Process, Procedural Due Process, and the Bill of Rights, 103 COLUM. L. REV. 833 (2003) (discussing pro se litigation and assistance of counsel).

156 See Hurtado v. California, 110 U.S. 516, 521-25 (1884); Murray's Lessee v. Hoboken Land \& Improvement Co., 59 U.S. (18 How.) 272, 276-77 (1856).

157 See generally JAMES C. HOLT, THE NORTHERNERS: A STUDY IN THE REIGN OF KING JOHN (Oxford Univ. Press, U.S. ed. 1992) (analyzing the rebellion against King John); RALPH V. TURNER, KING JOHN: ENGLAND'S EVLL KING? (2009 ed.) (discussing various interpretations of King John's rule);

158 Andrew Caplen, The Magna Carta, a One Nation Justice Policy, Access to Justice and the Role of the Church, 175 LAw \& JUST. - CHRISTIAN L. REV. 166, 166-67 (2015).

159 See id. at $166-67$.

$160 \mathrm{Id}$. at 167. 
Carta. ${ }^{161}$ Over the course of the following hundreds of years, the agreement was modified in several ways by various monarchs. ${ }^{162}$

The protections in the Magna Carta were intended to protect citizens from the king and guarantee a right to be free from the "oppressions and usurpations of his prerogative." 163 In order to protect against these usurpations, the Magna Carta laid out several rights that citizens of the England could claim against their lords. ${ }^{164}$ Most critical to procedural due process was clause twenty-nine:

No freeman is to be taken or imprisoned or disseised [sic] of his free tenement or of his liberties or free customs, or outlawed or exiled or in any way ruined, nor will we go against such a man or send against him save by lawful judgement of his peers or by the law of the land. To no-one will we sell or deny of [sic] delay right or justice. ${ }^{165}$

Elements of clause twenty-nine also appeared in many of the charters in the original thirteen colonies. The Massachusetts Bay Company charter states that all the colonists would "have and enjoy all liberties and immunities of free and natural subjects." 166 Sir Edward Coke, who was an English judge at the time of the establishment of the thirteen colonies, heavily commented on the nature of the procedural rights that the Magna Carta gave to citizens against the English monarchy. ${ }^{167} \mathrm{He}$ even authored some of the various charters that established the colonies. ${ }^{168}$ In particular, Coke was of the opinion that although the Magna

161 See id.

162 See Albert Beebe White, Note, The Name Magna Carta, 30 ENG. Hist. Rev. 472, 472-75 (1915) (discussing various revisions and versions of the magna carta); see also Albert Beebe White, Note, Note on the Name Magna Carta, 32 ENG. HIST. REV. 554, 554 55 (1917). See generally DAVID CARPENTER, THE STRUGGLE FOR MASTERY: THE PENGUIN HISTORY OF BRITAIN 1066-1284 (Penguin ed. 2004) (detailing the reign of King John); FatTH Thompson, Magna Carta: ITS Role IN THE Making Of The ENglish CONSTITUTION 1300-1629 (2d prtg. 1948) (discussing the significance of the Magna Carta in its early period).

${ }^{163}$ Hurtado v. California, 110 U.S. 516, 532 (1884).

164 Id.

${ }^{165}$ See Magna Charta of John, ch. 29 (1215), reprinted in Magna Carta Translation, NAT'L ARCHIVES (2007) https://www.archives.gov/exhibits/featured-documents/magnacarta/translation.html [https://perma.cc/MD38-MHLQ].

166 The Charter of Massachusetts Bay: 1629, AVALON PROJECT, http://avalon.law.yale.edu/17th_century/mass03.asp [https://perma.cc/DKP4-Q5E5]. The Virginia charter also had similar language stating that colonists would have the same "[l]iberties, [f]ranchises and [i]mmunities" as people born in England. The First Charter of Virginia; April 10, 1606, AVALON PROJECT, http://avalon.law.yale.edu/17th_century /va01.asp [https://perma.cc/923D-ULC6].

${ }^{167}$ See generally THOMPSON, supra note 162 (discussing the significance of Coke's scholarship on the interpretation of the Magna Carta in its early period); Ralph Turner, The Meaning of Magna Carta Since 1215, 53 HIST. TODAY, Sept. 2003 (discussing Coke's comments on the concessions that King John was forced to make in the Magna Carta).

${ }^{168}$ See RalPH V. Turner, Magna Carta: Through the AGES, 208-09 (Routledge 2014) (2003) [hereinafter TURNER, MAGna CARTA]. See generally DANNy DANZINGER \& 
Carta provided protections against the King's arbitrary actions, the Parliament of England (as a body of the people) was able to supersede the protections in the Magna Carta. ${ }^{169}$ Over the course of the implementation of the Magna Carta, and pursuant to Coke's theory of parliamentary supremacy, the procedural protections against the government became merely window dressing. ${ }^{170}$

The Founding Fathers, however, when drafting the Constitution, took this weakening of the Magna Carta into consideration. ${ }^{171}$ They purposefully diverged from the precedent of the British interpretation of the Magna Carta's protections. ${ }^{172}$ The framers "explicitly rejected [the British] theory of the government." 173 Instead, the Constitution explicitly limits the power of the government (not just the monarchs). ${ }^{174}$ As the U.S. Supreme Court has articulated, the British inspired due process requirement was not "essential to that 'due process of law,' when applied to prosecution for felonies." 175 Instead, it was used as an illustration. ${ }^{176}$

Ultimately, the U.S. Constitution borrowed substantially from the underpinnings of the Magna Carta to prevent government infringement against individuals, with the intent to prevent arbitrary executive and legislative action against individuals (i.e., to prevent vis et voluntas). ${ }^{177}$ Many constitutional amendments (the Fourth, Fifth, and Sixth to name a few) have been explicitly linked to the Magna Carta's protection of due process. ${ }^{178}$

\section{B. American Pro Se Due Process Rights}

The Constitution embodied procedural due process rights in several amendments ${ }^{179}$ - for criminal purposes, the most important is the Sixth Amendment. The Sixth Amendment reads:

John Glllingham, 1215: The Year of Magna Carta (Touchstone 2004) (2003)

(discussing the creation of the Magna Carta); ClaIRE BREAY, MAGNA CARTA: MANUSCRIPTS AND MYTHS ( $2 \mathrm{~d}$ ed. 2010) (exploring the context in which the Magna Carta was issued).

${ }^{169}$ Under Coke's interpretation, the "omnipotence of Parliament over the common law was absolute, even against common right and reason." TURNER, MAGNA CARTA, supra note 168, at 217 (quoting Hurtado v. California, 110 U.S. 516, 531 (1884)).

170 See id. at 217.

171 Id. at 216-17.

172 Martin H. Redish \& Lawrence C. Martin, Adjudicatory Independence and the Values of Procedural Due Process, 95 YALE L.J. 455, 461 (1986).

173 Id.

174 Id. The Founders response in the U.S. Constitution was analogous to the British placing limitations on parliament's right to imprison or fine citizens. See id.

175 Hurtado v. California, 110 U.S. 516, 520 (1884).

176 Id. at 523 .

177 See generally Redish \& Martin, supra note 172 (noting that the constitutional system sought to ensure limited government).

178 See Klopfer v. North Carolina, 386 U.S. 213, 223 (1967) (holding that the Fourteenth Amendment incorporates the Sixth Amendment's right to a speedy trial and applies to the states).

179 See e.g., U.S. CONST. amends. V, VI, XIV. 
In all criminal prosecutions, the accused shall enjoy the right to a speedy and public trial, by an impartial jury of the State and district wherein the crime shall have been committed, which district shall have been previously ascertained by law, and to be informed of the nature and cause of the accusation; to be confronted with the witnesses against him; to have compulsory process for obtaining witnesses in his favor, and to have the Assistance of Counsel for his defence. ${ }^{180}$

Although the Sixth Amendment does not explicitly guarantee a selfrepresentation right, as described below, the phrase "to be confronted with the witnesses against him" has been interpreted by the Court to recognize a constitutional right to appear pro se. ${ }^{181}$

The canonical interpretation and articulation for the procedural right to proceed pro se comes from Faretta v. California. ${ }^{182}$

In Faretta, while on trial for charges of grand theft, Faretta asked to dispose of the public defender given to him and instead asked to represent himself. ${ }^{183}$ Faretta argued that he had represented himself previously in a criminal prosecution and was concerned that the public defender was "very loaded down with ... [a] heavy case load."184

The judge initially accepted Faretta's decision but reserved the right to reverse it if he determined that Faretta was "unable adequately to represent himself." 185 Before the trial, the judge questioned Faretta about various aspects of litigation, including the hearsay rule and preemptory challenges in voire dire. ${ }^{186}$ Although Faretta had appropriate answers to these questions, the judge determined that Faretta "had not made an intelligent and knowing waiver of his right to the assistance of counsel, and also ruled that Faretta had no constitutional right to conduct his own defense."187

The Supreme Court then was faced with the question of whether a "[s]tate may constitutionally hale a person into its criminal courts and there force a lawyer upon him, even when he insists that he wants to conduct his own defense."188 In making its decision the Court articulated the importance of allowing defendants the right of self-representation in federal courts. ${ }^{189}$

180 U.S. CONST. amend. VI.

${ }^{181}$ Faretta v. California, 422 U.S. 806, 818-19 (1975).

182 Id. at $835-36$.

183 Id. at 807.

$184 \mathrm{Id}$.

$185 \mathrm{Id}$. at 808.

186 Id.

${ }^{187}$ Faretta, 422 U.S. at 809-10.

188 Id. at 807.

${ }^{189} \mathrm{Id}$. at $812-13$ ("[T] the beginnings of our Nation. Section 35 of the Judiciary Act of 1789, 1 Stat. 73, 92, enacted by the First Congress and signed by President Washington one day before the Sixth Amendment was proposed, provided that 'in all the courts of the United States, the parties 
Justice Stewart, in writing for the majority, harkened back to previous holdings that recognized a constitutional right to proceed pro se. ${ }^{190}$ In Adams $v$. United States ex rel. McCann, the Court held that the Sixth Amendment right to counsel implicitly "embodies a 'correlative right to dispense with a lawyer's help." "191 As long as a waiver of counsel is intelligent and free, it must be respected by federal courts. ${ }^{192}$

Once establishing that there was federal precedent for not forcing a lawyer upon an individual when the individual so chooses, the Court in Faretta went into a digression on the underlying rationales of proceeding pro se. ${ }^{193}$ Here the Court harkened back to English and colonial jurisprudence from which the Sixth Amendment arose. ${ }^{194}$ The Court articulated the history of the Star Chamber (the sixteenth and seventeenth century adjudicating body in British criminal jurisprudence). ${ }^{195}$ In the Star Chamber, counsel was forced upon a defendant and when a counsel refused to sign a non-guilty plea, the defendant was presumed to have confessed. 196 Eventually this process was swept away precisely because it allowed the government to impose penalties essentially arbitrarily and deprive its citizens of life and liberty without adequate safeguards. ${ }^{197}$

But the American colonists brought with them an even stronger commitment to protecting a self-representation right than was endorsed in England. The Colonists distrusted lawyers as the "lawyer was synonymous with the cringing Attorneys-General and Solicitors-General of the Crown and the arbitrary Justices of the King's Court, all bent on the conviction of those who opposed the King's prerogatives ...."198 The Colonists understood the danger to personal liberties when governments could arbitrarily make decisions-

may plead and manage their own causes personally or by the assistance of ... counsel ...." ")

190 Id. at 814.

191 Adams v. United States ex rel. McCann, 317 U.S. 269, 279 (1942).

192 Id. at 275.

193 Faretta, 422 U.S. at 814-16, 821 .

194 Id. at 821 .

195 Id. at $821-23$.

196 Id. at $821-22$.

197 "There is something specially repugnant to justice in using rules of practice in such a manner as to debar a prisoner from defending himself, especially when the professed object of the rules so used is to provide for his defence." Id. at 822-23 (citing JAMES STEPHEN, A History OF THE CRIMINAL LAW OF ENGLAND 341-42 (1883)).

The court of the star chamber was an efficient, somewhat arbitrary arm of royal power. . . . it was not a competitor of the common law so much as a limitation on it $-\mathbf{a}$ reminder that high state policy could not safely be entrusted to a system so chancy as English Law.

Id. at 821 n. 17 (citing LAWRENCE FRIEDMAN, A HISTORY OF AMERICAN LAW 23 (1972)). 198 Id. at 826 (quoting ChARLES WARREN, A HISTORY OF THE AMERICAN BAR 7 (1911)). 
allowing self-representation was a safeguard to protect citizens from the government's agents. ${ }^{199}$

The key to the Court's understanding of the right of self-representation was that in times of criminal prosecutions, it was a matter of justice to allow citizens to have available to them all potential defenses. ${ }^{200}$ The protection of the individual from the government's power of deprivation was critical to the Court's ruling in Faretta that pro se representation is a constitutionally protected right: ${ }^{201}$

To force a lawyer on a defendant can only lead him to believe that the law contrives against him.... The defendant, and not his lawyer or the State, will bear the personal consequences of a conviction.... And although he may conduct his own defense ultimately to his own detriment, his choice must be honored out of "that respect for the individual which is the lifeblood of the law." 202

The U.S. due process pro se right has been articulated in cases even after Faretta. ${ }^{203}$ And these cases and scholars seem to all agree that the due process rights we have in place do arise from the need to protect individuals from government powers of fines and imprisonment. ${ }^{204}$

The Sixth Amendment in connection with the Fourteenth Amendment grants an individual a state and federal criminal pro se right. ${ }^{205}$ But selfrepresentation is not limited to the criminal context. The federal government has explicitly extended this right to the civil context. ${ }^{206}$ The right has been codified in 28 U.S.C. $\S 1654 .{ }^{207}$ This federal civil right simply arises out of the same kind of rationale as the criminal Sixth Amendment right and general due process

${ }^{199}$ See Faretta, 422 U.S. at 826.

$200 \mathrm{Id}$. at 834 n.45.

201 See id. at 833-34.

$202 \mathrm{Id}$. at 834 (quoting Illinois v. Allen, 397 U.S. 337, 350-51 (1970) (Brennan, J., concurring)).

203 See McCoy v. Louisiana, 138 S. Ct. 1500, 1507-08 (2018). See generally McKaskle v. Wiggins, 465 U.S. 168 (1984) (articulating the bounds of the pro se right).

204 See Frank I. Michelman, Formal and Associational Aims in Procedural Due Process, in Due Process: Nomos XVIII, at 131-33 (J. Roland Pennock \& John W. Chapman eds., 1977); Frank H. Easterbrook, Substance and Due Process, 1982 SUP. CT. REV. 85, 101; Rubin, supra note 155, at $873 \mathrm{n} .175$ ("Presumably, the strength of an individual's interest in his life, and the value, in light of that, of a predeprivation hearing, will mean that the balance in any ordinary procedural due process case, that is, one not involving a 'random and unauthorized' deprivation, will always require a hearing before one is deprived of that interest." (citation omitted) (quoting Parratt v. Taylor, 451 U.S. 527, 541 (1981))); Laurence H. Tribe, Structural Due Process, 10 HARV. C.R.-C.L. L. REv. 269, 269 (1975).

205 Faretta, 422 U.S. at 818-19, 832.

20628 U.S.C. $\$ 1654$ (2012).

207 Id ; see also supra notes 50-51 and accompanying text. 
concerns stemming from the Magna Carta. 208 That is, that civil deprivations of life and liberty implicate giving individuals a pro se right.

State civil pro se rights also arise out of constitutional considerations but in a slightly different way. Most scholars view the state civil pro se right as an outlay of the procedural due process considerations of the Fifth and Fourteenth Amendments. ${ }^{209}$ These scholars argue that the Fifth and Fourteenth Amendments guarantee adequate access to the court system. ${ }^{210}$ Implicit in this right of access is the right to self-representation: "Although a constitutional right of self-representation must therefore be inferred from the recognized right of access to courts, it is presently protected under both federal statute and the constitutions and statutes of 15 states." 211 Again, the protections of the individual's deprivations are implicated.

Although this constitutional link is important, practically speaking, every state has guaranteed both a civil and criminal pro se right for individual litigants at this current time. ${ }^{212}$

It is this exact above history of procedural due process and, in turn, the right to proceed pro se (stemming from the Magna Carta, Fifth, Sixth, and Fourteenth Amendments) that underlies why corporations should be extended pro se rights. If, given our history with due process and pro se rights, the importance of protecting individuals from government is key, then this rationale is just as important in the individual context as it is in the corporate context. As I will argue below, individuals in corporations are equally at risk of being injured arbitrarily by government criminal or private civil sanctions. If this is the case, then it stands to argue that protecting those individuals in corporations is critical. As such, granting a corporate pro se right makes sense if we really want to protect individuals from deprivations of life and liberty.

208 See GOLDSCHMIDT ET AL., supra note 71, at 24 (noting that "constitutional case law, federal legislation, and state law-not to mention the Magna Carta establish the legal foundation for self-representation"). The federal civil pro se right reads in part: "In all courts of the United States the parties may plead and conduct their own cases personally or by counsel as, by the rules of such courts, respectively, are permitted to manage and conduct causes therein." 28 U.S.C. $\S 1654$.

${ }^{209}$ See GOLDSCHMIDT ET AL., supra note 71, at 19-20; Eric J.R. Nichols, Note, Preserving Pro Se Representation in an Age of Rule 1/ Sanctions, 67 TEX. L. REV. 351, 379 (1988); Drew A. Swank, Note and Comment, The Pro Se Phenomenon, 19 BYU J. PUB. L. 373,375 (2005).

210 See GOLDSCHMIDT ET AL., supra note 71, at 19,21 ("[T] he right of self-representation has been alternatively traced to the privileges and immunities clause."). The state pro se right stemming from the Fifth Amendment started with the right of representation of litigants having access to the court system. See Boddie v. Connecticut, 401 U.S. 371, 379 (1971) (finding that the due process clause prohibits states from limiting the access of litigants to the court system); Armstrong v. Manzo, 380 U.S. 545, 552 (1965).

211 GoLDSCHMIDT ET AL., supra note 71, at 23.

212 Forty-nine states and the District of Columbia have some statute or constitutional amendment guaranteeing the right to appear pro se in both civil and criminal proceedings. See id. at 130-34. 


\section{The Corporate Pro Se Litigant}

Thus far, I have argued that the existing rationales for denying business organizations a pro se right do not stand up to even the lowest level of scrutiny. But it's not enough to simply argue that there are no good reasons to deny business organizations a pro se right. In this section, I offer a positive reason to affirmatively extend the due process right to business organizations.

The underlying rationale for due process rights is the protection of the individual. ${ }^{213}$ Individuals should be granted all available opportunities to defend themselves from arbitrary government action, in particular from impositions of criminal sanctions and prison time. ${ }^{214}$

My argument in the section proceeds in two parts. First, I argue that corporate criminal and civil litigation does affect individuals in the corporation in a significant way. These effects are particularly important in business organizations that are small (member-managed LLCs and partnerships). ${ }^{215} \mathrm{But}$ this is not to say that the argument does not apply to large public corporations as well. Using classical economic conceptions of the firm, ${ }^{216} \mathrm{I}$ argue that damage to lower-level employees is also an important consideration when

213 See id. at 20-21; Michelman, supra note 204, at 126 ("One familiar notion of due process is that of an obligation on the part of those who make decisions about the concerns of other individuals to engage in explanatory procedures . . . in which agents state reasons for their decisions and affected individuals are allowed to examine and contest the proffered reasons."); Rubin, supra note 155, at $838 \mathrm{n} .19$ (explaining the etymology of "due process of law," tracing it back to the Magna Carta as an instrument "intended to secure the individual from the arbitrary exercise of the powers of government" (quoting Bank of Columbia v. Okely, 17 U.S. (4 Wheat.) 235, 244 (1819))).

214 Cf. Tribe, supra note 204 , at 291 ("[T] conduct should be defined as criminal, although it says a great deal about the design of the process of identifying and punishing criminals, and it often specifies procedural constraints whose importance goes far beyond their likely impact on the accuracy of trial results." (footnote omitted)).

215 See, e.g., DAVID MCKNIGHT \& PAUL Hinton, U.S. CHAMBER INST. FOR LEGAL REFORM, TORT LIABILITY COSTS FOR SMALL BUSINESSES 3 (Oct. 2020), https://institute forlegalreform.com/wp-content/uploads/2020/10/FINAL-Small-Business-Tort-Costs- 10 . 20.20.pdf [https://perma.cc/55QZ-LH8S] ("[T] he burdens of the tort system vary significantly across firms of different sizes, and the smallest businesses have disproportionately higher costs. The tort liability ... for companies with under $\$ 1$ million in annual revenue is more than 10 times larger than that of companies with over $\$ 50$ million in annual revenue.").

216 Others have implicated economic theories to argue for constitutional rights for corporations. See, e.g., Larry E. Ribstein, Corporate Political Speech, 49 WASH. \& LEE L. REV. 109, 130-34 (1992) (applying economic justifications for the First Amendment to corporations' free speech rights). They most generally argue that since corporations are aggregations of individuals according to economists, that the extension of constitutional rights to corporations is simply a recognition of the individuals in the corporation having those exact rights. See Meese \& Oman, supra note 35, at 280 (arguing that the holding in Sebelius v. Hobby Lobby Stores, Inc., 723 F.3d 1114 (10th Cir. 2013), is consistent with the corporate theory of the firm). 
contemplating pro se rights. Second, I respond to some potential criticisms of extending the pro se right to business organizations.

\section{A. Effects of Corporate Criminal/Civil Litigation on Individuals}

Corporate litigation can have severe effects on the members of a corporation. ${ }^{217}$ When a business organization is sued either criminally or in a large civil suit, monetary sanctions can cause severe externalities within the corporation. ${ }^{218}$

The simplest example of this is a manager-owned LLC. In the example in the introduction, the owners of an LLC were the sole managers of the company. ${ }^{219}$ When the owners were sued for trademark infringement, the owners personally and the company as a separate entity were both sued. ${ }^{220}$ It is clear that the owners could represent themselves in the lawsuit and attempt to defend themselves. ${ }^{221}$ This, however, was not the case with the LLC. The owners could not appear on behalf of the LLC. ${ }^{222}$ It's not enough to give the owners an individual pro se right to protect the individual owners from harm. If the LLC was to lose its lawsuit, this would have drastic consequences for the two owners. ${ }^{223}$

Take, for example, a sole member of an LLC (or sole shareholder in a corporation). This owner would potentially lose her job, her livelihood, maybe even her savings. ${ }^{24}$ This is the same potential outcome had the sole member lost the individual lawsuit. We gave the owner a pro se right to protect her individually but denied her company a pro se right, even though giving it a pro se right is just another way to protect the individual. ${ }^{225}$ If due process is really

217 See In re Kemp \& Beatley, Inc., 473 N.E.2d 1173, 1178 (N.Y. 1984) ("[The owner's] participation in that particular corporation is often his principal or sole source of income. ... [H]e looks to his salary for the principal return on his capital investment ...." (quoting 1 F.H. O’Neal, Close CoRPORATIONS $\S 1.07$ (2d ed. 1971))); MCKNIGHT \& HINTON, supra note 215 , at 11 . (showing that tort liability cost small businesses $\$ 182$ billion in 2018).

218 See In re Kemp \& Beatley, Inc., 473 N.E.2d at 1178; cf. Frank H. Easterbrook \& Daniel R. Fischel, Limited Liability and the Corporation, 52 U. CHI. L. REV. 89, 104-05 (1985) (noting that employees of the corporation are "voluntary creditors" who bear the risk of insolvency).

219 See Drake Complaint, supra note 1, at 1-2.

220 See id.

${ }^{221}$ See Notice of Pro Se Appearance by Ziad Khoury, Drake v. Zen Bakeries, LLC, No. 1-14-CV-00999 (S.D.N.Y. A pr. 28, 2014); Notice of Pro Se Appearance by Mais Karadsheh, Drake v. Zen Bakeries, LLC, No. 1-14-CV-0009 (S.D.N.Y. Apr. 28, 2014).

222 See Order Filed April 30, 2014, supra note 6, at 1.

223 See supra note 217.

224 See In re Kemp \& Beatley, Inc., 473 N.E.2d 1173, 1178 (N.Y. 1984) ("[E]arnings of a close corporation, as is well known, are distributed in major part in salaries, bonuses and retirement benefits." (quoting 1 F.H. O’NEAL, ClOSE CORPORATIONS $§ 1.07$ (2d ed. 1971))).

225 One might argue that it's enough to give the individual a pro se right. But this is not the case because the standards of liability for the individual and the corporation are not the 
about protecting individuals from harm (both prison and prohibitive sanctions), then in the sole-member context, giving full due process rights to the corporate entity furthers this individual-oriented goal.

Closely held corporations make up the majority of the corporations in America. ${ }^{226}$ For these owner-managed corporations, having the ability to represent themselves will save these corporations attorneys' fees. ${ }^{227}$ When faced with a lawsuit, particularly one with no merit, the corporation or partnership will not be burdened by having to hire any attorney to avoid a default judgment. Appearing pro se will save the corporation money and time, allowing it to more readily carry out its business. ${ }^{228}$

The example of the sole member in an LLC or sole shareholder in a corporation is an easy case. When it is a defendant in a lawsuit, giving the corporate entity a pro se right protects the one individual owner's due process right. That's simple enough and is reason enough to extend the right to the corporation. It's also simple because the fate of the corporation with respect to the litigation is synonymous with the fate of the individual. ${ }^{229}$

same. It could be case that the individual wins his own lawsuit but his corporation loses the lawsuit on the same facts. In that case, the system has hurt the owner via his corporation by not giving the corporation (and in turn the individual) a pro se right. For discussions on the differences in proving liability for a corporation and an individual, see Lawrence Friedman, Essay, In Defense of Corporate Criminal Liability, 23 HARV. J.L. \& PUB. POL'Y 833, 837 n.18, 858 (2000); V.S. Khanna, Corporate Criminal Liability: What Purpose Does It Serve?, 109 HARV. L. REV. 1477, 1492, 1512-20 (1996); and Frederic P. Lee, Corporate Criminal Liability, 28 COLUM. L. REV. 1, 1-2 (1928).

${ }^{226}$ It's important to note that most corporations are closely held. Only a small percentage of corporations in the United States are large and publicly held. Closely Held Corporations, INC., http://www.inc.com/encyclopedia/closely-held-corporations.html (on file with the Ohio State Law Journal) (last updated Feb. 6, 2020) ("Over 90 percent of all businesses in the United States are closely held.").

227 The existence of technology startups (e.g., LegalZoom, Clerky, UpCounsel, Casetext) that attempt to streamline easy legal work for small businesses is evidence of the demand for cheaper services. E.g., David Orozco, The Use of Legal Crowdsourcing ("Lawsourcing") to Achieve Legal, Regulatory, and Policy Objectives, 53 AM. BuS. L.J. $145,181-82$ (2016). It's certainly too expensive for a small company to either have a lawyer on staff or keep one on retainer. See U.S. CHAMBER INST. FOR LEGAL REFORM, TORT LIABILITY COSTS FOR SMALL BUSINESS 6 (July 2010), https://instituteforlegalreform.com/wp-content/uploads/2020/10/

ilr_small_business_2010_0.pdf [https://perma.cc/89JP-2ZH9] ("In a 2007 Harris poll of business owners/managers who indicated that they were somewhat or very concerned about frivolous or unfair lawsuits, $62 \%$ said they make business decisions to avoid lawsuits. ... [of those who had a suit filed against them in the prior ten years,] $64 \%$ said business suffered because litigation was very expensive."); see also id. at 1 ("[In 2008] [s]mall businesses bore $81 \%$ of business tort liability costs but only took in only $22 \%$ of the revenue.").

${ }^{228}$ See, e.g., Ed Finkel, The Pro Se Revolution, 105 ILL. B.J., Oct. 2017, at 22, 24.

${ }^{229} \mathrm{Cf}$. Easterbrook \& Fischel, supra note 218, at 89 ("[T] he corporation is not real. It is no more than a name for a complex set of contracts among managers, workers, and contributors of capital. It has no existence independent of these relations."). 
But one might argue that large corporations are not as easy of a case, as they are more complex and contain several people with several different roles. ${ }^{230} \mathrm{As}$ such, damage to the corporate entity has differing impacts on differing people. Although a pro se right need not extend past small corporations and partnerships defending themselves, the argument posed here does logically extend to public and other large business organizations.

In a public corporation, shareholders are classically considered to be the owners or principals, while high-level executives are considered to be managers of the firm or agents. ${ }^{231}$ Classic corporate theory also posits that companies are to be run for the interests of the shareholders; as such, a lawyer or a manager making decisions on behalf of the company should make them with the goal of maximizing profit for shareholders. ${ }^{232}$ Under this theory, it's hard to see how corporate lawsuits hurt members of the corporation. Shareholders are often wealthy and diversified. ${ }^{233}$ Prohibitive sanctions or even bankruptcy due to sanctions don't likely affect shareholders (at least not in the same way they did the owner-managed). ${ }^{234}$ Furthermore, the managers and high-level executives are also likely not affected in the same way the sole member in a LLC or sole shareholder in a corporation is when the entity is sued. ${ }^{235}$ If we consider the shareholders and the managers as the critical members of the corporation, extension of pro se rights make less sense.

230 See Eugene F. Fama \& Michael C. Jensen, Separation of Ownership and Control, 26 J.L. \& ECON. 301, 308 (1983).

231 The owner is understood to delegate residual control rights to her agents (in the corporate context, the board of directors) who in turn are charged with managing the assets in the principal's interest, perhaps through several more layers of delegation. For classic conceptions of the theory of the firm, see generally Eugene F. Fama, Agency Problems and the Theory of the Firm, 88 J. POL. ECON. 288 (1980) [hereinafter Fama, Agency Problems]; Fama \& Jensen, supra note 230; and Michael C. Jensen \& William H. Meckling, Theory of the Firm: Managerial Behavior, Agency Costs and Ownership Structure, 3 J. FIN. ECON. 305 (1976). Legal scholarship has also adopted the principal-agent viewpoint. See Lucian Arye Bebchuk, Federalism and the Corporation: The Desirable Limits on State Competition in Corporate Law, 105 HARV. L. REV. 1435, 1463-65 (1992); Bernard S. Black, Shareholder Passivity Reexamined, 89 MICH. L. REV. 520, 522-25 (1990). But see Victor Brudney, Corporate Governance, Agency Costs, and the Rhetoric of Contract, 85 COLUM. L. REV. 1403, 1428 (1985).

232 See Fama, Agency Problems, supra note 231, at 288-89. The issue of how a lawyer should represent the interests of a corporation is discussed further below. See infra Part V.B.1.

233 See Fama, Agency Problems, supra note 231, at 291.

234 See Piercing the Corporate Veil: When LLCs and Corporations May Be at Risk, NOLO, https:/www.nolo.com/legal-encyclopedia/personal-liability-piercing-corporate-veil33006.html [https://perma.cc/Q3KH-B6RE].

235 Although managers are likely more effected than shareholders as they routinely have contracts that tie a portion of their pay to stock. See supra note 231 . 
However, according to some economic theories of the firm, ${ }^{236}$ all production members of a corporation (including lower-level employees) are important pieces to the longevity of the corporation. ${ }^{237}$ The firm, then, is a team that functions together to produce joint output. ${ }^{238}$ Armen A. Alchian and Harold Demsetz argue the correct way to understand a firm is through this team dynamic. $^{239}$ A team consists of individuals who make firm-specific investments. ${ }^{240}$ Only when each member of the team is incentivized to stay inside the firm does the firm actually exist and make a profit. ${ }^{241}$ The problem is that most team output is joint output and is difficult to apportion fairly. ${ }^{242}$

Since each individual knows that dividing up the output fairly is difficult, in order to make the initial investment, the individual must be ensured that her investment will be protected. ${ }^{243} \mathrm{~A}$ corporation ensures this by allocating the proceeds (profit) of the team effort such that each person chooses to stay inside the firm. ${ }^{244}$

But the question remains: Who determines how proceeds are allocated and who is the source of holding the team together? Alchian and Demsetz argue here: "[i]t is the centralized contractual agent in a team productive process - not some superior authoritarian directive or disciplinary power." 245 The manager of the team (a high-level executive in the corporate context) is the director who

236 Although I use Alchian and Demsetz, infra note 237 and accompanying text, one could also point to the transaction costs economists to argue that the individuals in the firm are the important unit of analysis. Most notably, Ronald Coase argued for the "nexus of contract" theory. See generally R.H. Coase, The Nature of the Firm, 4 ECONOMICA 386 (1937). For Coase, there are substantial costs to contracting with people. Id. at 390-92. When these costs become prohibitive, it's cheaper for shareholders to bring contracting parties inside the firm rather than create explicit contracts outside the firm. Id. Corporations, then, are just instances of contracting efficiency. They do not have a personality or entity status in their own right. Id. They are simple aggregates of the various versions of contracts that shareholders wish to employ. See generally R.H. Coase, The Nature of the Firm, 4 ECONOMICA 386 (1937); Jensen \& Meckling, supra note 231; Scott E. Masten, A Legal Basis for the Firm, 4 J.L. ECON. \& ORG. 181 (1988).

237 E.g., Armen A. Alchian \& Harold Demsetz, Production, Information Costs, and Economic Organization, 62 AM. ECON. REV. 777, 777-78, 785 (1972).

238 See id. at 794; see also Masten, supra note 236, at 183-86.

239 Alchian \& Demsetz, supra note 237 , at 778.

240 Id. at 779.

241 See id. at 777-80.

242 Id. at 779 ("With team production it is difficult, solely by observing total output, to either define or determine each individual's contribution to this output of the cooperating inputs. The output is yielded by a team, by definition, and it is not a sum of separable outputs of each of its members." (emphases omitted)).

243 Id. at $778-79$.

244 Margaret M. Blair \& Lynn A. Stout, A Team Production Theory of Corporate Law, 85 VA. L. REV. 247, 278 (1999) ("[H]ierarchy can perform a third function .... This third function is encouraging firm-specific investment in team production by mediating disputes among team members about the allocation of duties and rewards." (emphasis omitted)).

245 Alchian \& Demsetz, supra note 237 , at 778 (emphasis omitted). 
must make sure that all team members stay inside the firm, and in order to do that, she must allocate proceeds among team members. ${ }^{246}$

Some legal scholars have adopted this viewpoint of the firm and have shown how corporate law as it stands today mimics this team production theory of the firm. ${ }^{247}$ Margaret M. Blair and Lynn A. Stout argue that the "public corporation is a team of people who enter into a complex agreement to work together for their mutual gain." 248 They term this view of the corporation the "team production theory" of the firm. ${ }^{249}$

The key insight of the team production theory of the firm for this article is the notion that corporations should not just be run in the interests of the shareholders-i.e., shareholders are not the only principals. Instead, the corporation should be run to protect each member of the corporation so as to make sure each member contributes the requisite effort into the team production function. 250

Managers then become the agents of all the members of the firm and are seen as the mediating hierarchies of the team. ${ }^{251}$ Rather than simply run the company in the interests of the shareholders, managers must coordinate efforts and returns to all members of the team, including lower-level employees. ${ }^{252}$

When the mediating function is added to the story of what hierarchy accomplishes, it is no longer obvious that employees should be viewed as agents of the hierarchs to whom they report, as the grand-design principalagent model suggests. Instead, it can be argued that hierarchs work for team

${ }^{246} \mathrm{Id}$. at 788 ("More effective control of corporate activity is achieved for most purposes by transferring decision authority to a smaller group, whose main function is to negotiate with and manage (renegotiate with) the other inputs of the team.").

${ }^{247}$ Blair \& Stout, supra note 244, at 286-87, 289 (noting that Blair and Stout, in addition to introducing this theory of the firm, argue that corporate law as it currently stands emulates and supports their team production theory).

248 Id. at 278.

249 Id. at 256.

250 Alchian and Demsetz, supra note 237, at 794; see also Blair \& Stout, supra note 244, at 264. Another way to get to this conclusion is through stakeholder theory. Stakeholder theory posits that firms should be run not just for shareholders but all relevant stakeholders to which the firm's actions have substantial effects. For classic arguments of stakeholder theory, see R. EDWARD FreEMAN, JEFFREY S. HARRISON \& ANDREW C. WICKS, MANAGING FOR STAKEHOLDERS: SURVIVAL, REPUTATION, AND SUCCESS 1-19 (2007). See generally R. Edward Freeman, The Politics of Stakeholder Theory: Some Future Directions, 4 BuS. ETHICs Q. 409 (1994); Kenneth E. Goodpaster, Business Ethics and Stakeholder Analysis, 1 Bus. ETHICS Q. 53 (1991).

251 Blair \& Stout, supra note 244 , at 278 ("Hence the mediating hierarchy of a corporation can be viewed as a substitute for explicit contracting that is especially useful in situations where team production requires several different team members to make various kinds of enterprise-specific investments in projects that are complex, ongoing, and unpredictable.").

252 Id. at $284-87$. 
members (including employees) who "hire" them to control shirking and rentseeking among team members. ${ }^{253}$

Blair and Stout are arguing here that employees should be seen as principals in the same regard as shareholders. ${ }^{254}$ All members of the firm are principals that "hire" a manager to make decisions on behalf of the whole team. ${ }^{255}$

It's clear then, from the team production model, that shareholders and managers are not the only important people inside the public corporation. ${ }^{256}$ Low-level employees are also critical to the team (corporation) sustaining profits and returns. ${ }^{257}$ The decision then to give a corporation a pro se right must include all the employees that exist in the corporation.

But why are lower-level employees at serious risk of harm in corporate lawsuits? In comparison to shareholders and to managers, it should be clear that lower-level employees are more at risk of harm. Unlike shareholders, employees cannot diversify their exposure to the corporation. ${ }^{258}$ They instead put all their investment (time and effort) into the corporation with the hopes of being rewarded with a salary and maybe even a bonus. ${ }^{259}$ Employees put their savings into a corporate retirement account increasing their exposure to potential corporate pitfalls. ${ }^{260}$ When a company loses a lawsuit or is found guilty, the subsequent sanction can have drastic effects on the employment and pensions of employees. ${ }^{261}$ Large lawsuits can create large layoffs, bankruptcy, and loss of profits. ${ }^{262}$

253 Id. at 280 .

254 Id.

255 Id.

${ }^{256} \mathrm{See}$, e.g., id. at 286 ("[O]ur claim [is] that directors should be viewed as disinterested trustees charged with faithfully representing the interests not just of shareholders, but of all team members ....").

${ }^{257}$ Blair \& Stout, supra note 244 , at 250.

258 See generally Heli C. Wang \& Jay B. Barney, Note, Employee Incentives to Make Firm-Specific Investments: Implications for Resource-Based Theories of Corporate Diversification, 31 ACAD. MGMT. REV. 466 (2006) (arguing that firm specific risk makes employees more or less likely to make firm specific investments given that they are fully exposed to firm risk).

259 See id. at $469-71$.

${ }^{260}$ See generally Ying Duan, Pouyan Foroughi, Edith S. Hotchkiss \& Yawen Jiao, Corporate Pensions and Financial Distress (Nov. 17, 2019) (unpublished manuscript) (on file with the Ohio State Law Journal) (arguing that defined benefit and defined contribution retirement plans impose significant losses on employees if a firm defaults or files for bankruptcy).

261 See, e.g., id. at 3.

262 See John C. Coffee, Jr., Making the Punishment Fit the Corporation: The Problems of Finding an Optimal Corporation Criminal Sanction, 1 N. ILL. U. L. REV. 3, 6 (1980); John C. Coffee, Jr., "No Soul to Damn, No Body to Kick": An Unscandalized Inquiry into the Problem of Corporate Punishment, 79 MICH. L. REV. 386, 401-02, 424-34 (1981) (criticizing publicity sanctions for their effects on employee layoffs); see also Christopher D. Stone, The Place of Enterprise Liability in the Control of Corporate Conduct, 90 YALE 
The criminal investigation of Enron is one such example. ${ }^{263}$ Enron's criminal lawsuits, fines and ultimate bankruptcy caused its employees a true deprivation of life and liberty. ${ }^{264}$ Thousands of employees struggled for new jobs in what was a difficult economy at the time. ${ }^{265}$ Some were even forced to sell their houses in order to pay medical bills. ${ }^{266}$ The company made thousands of layoffs ${ }^{267}$ in response to criminal lawsuits and criminal fines imposed by the Department of Justice. 268

Take, for example, mass layoffs. Imagine a case where in a depressed economy a large employer accounting for the majority of the employment in a city is sued, goes bankrupt, and lays off almost all of its employees. ${ }^{269}$ These

L.J. 1, 68 (1980); Christopher Kennedy, Comment, Criminal Sentences for Corporations: Alternative Fining Mechanisms, 73 CALIF. L. REV. 443, 455 (1985) ("A fine that forces an austerity program may result in employee layoffs."). See generally Jennifer Arlen, The Potentially Perverse Effects of Corporate Criminal Liability, 23 J. LEGAL STUD. 833 (1994) (arguing that current criminal liability sanctions of corporations have spillover effects on innocent parties and are not terribly effective in deterring crime).

263 See Rick Bragg, Enron's Collapse: Workers; Workers Feel Pain of Layoffs and Added Sting of Betrayal, N.Y. TIMES, Jan. 20, 2002, at $1 \S 1$.

${ }^{264}$ I do not mean to conclude that giving Enron a pro se right would have protected these employees. It likely would not have. The purpose of alluding to Enron here is simply to show that civil and criminal actions against a corporation have real tangible effects on certain employees of those corporations. See, e.g., id.

265 Id.

266 Id. ("Some longtime Enron employees lost hundreds of thousands of dollars as the value of stock they accumulated in Enron's boom times tumbled in a period when they were not allowed to sell it. Some lost a precious weekly paycheck and crucial health benefits. One employee's wife has had two strokes over the past two weeks, and the family has no way to pay the bills.").

267 Id.

268 The scholarship on Enron's criminal investigation and ultimate demise is too extensive to fully cite, but the following are a representative sample. See generally Kathleen F. Brickey, From Enron to WorldCom and Beyond: Life and Crime After Sarbanes-Oxley, 81 WASH. U.L.Q. 357 (2003) (exploring how, following Enron and WorldCom scandals, the Sarbanes-Oxley Act has made significant strides in combatting corporate silence); Geraldine Szott Moohr, An Enron Lesson: The Modest Role of Criminal Law in Preventing Corporate Crime, 55 Fl.A. L. REV. 937 (2003) (analyzing how criminal law can contribute most effectively to the prevention of "future Enrons"); Christopher A. Wray \& Robert K. Hur, Corporate Criminal Prosecution in a Post-Enron World: The Thompson Memo in Theory and Practice, 43 AM. CRIM. L. REV. 1095 (2006) (explaining how Enron lead the federal government to increase its focus on rooting out corporate fraud).

${ }^{269}$ Here, one can harken back Detroit's unemployment rate during the recession. In response to bailouts and Chapter 11 bankruptcy of Chrysler and General Motors, the companies laid off almost 100,000 employees combined. John Nichols, Auto Bailout Blues: Spin, Lies and Layoffs, NATION (May 16, 2009), http://www.thenation.com/article/autobailout-blues-spin-lies-and-layoffs/ (on file with the Ohio State Law Journal). The unemployment rate jumped to $27 \%$ by October of 2009 . Id. During this time Detroit's unemployment rate was more than double that of Michigan as a whole. Id. For more information on Detroit's unemployment at that time, see generally Detroit's Unemployment Rate Is Nearly 50\% According to the Detroit News, HuFfPost (Mar. 18, 2010), 
employees now have lost their source of income. They will have difficulty providing for their families and certainly have difficulty finding other jobs given the depressed economy and dynamics of the city: "The innocent shareholder is in a very different position from other innocent actors - such as employees and suppliers - who . . . may be hurt by the broad sweep of a corporate fine."270

These effects of corporate lawsuits on individuals seem to be similar to the effects of criminal sanctions on individuals. At their base, both types of lawsuits have dangerous effects on individuals such that we should want to protect those individuals in every procedural way possible. In the individual context, this means giving individuals a pro se right, and in the corporate context, it should mean giving a corporation a pro se right (because this serves the same due process purpose of protecting individuals from inaccurate harm).

\section{B. Critiques of the Corporate Pro Se Right}

At this point, even after scrutinizing the rationales posed by the courts and after purposing positive rationales for extending the pro se right to representation to corporations, one might argue that a corporate pro se right is not practical or needed because: (1) a corporation cannot represent itself because it is too diverse an organization to be trusted to a non-lawyer, i.e., no one person could effectively weigh the competing interests in a corporation so as to effectively appear on behalf of it in a pro se manner; (2) a manager representative might be shareholder friendly and, in turn, hurt low-level employees; and (3) a sole member is not at risk of injury when her LLC is sued, because limited liability protects the member.

\section{A Manager Is Not Capable of Representing a Corporation}

One might argue that a lawyer is more capable of managing the various interests in a corporation than a manager. However, a small business organization that is owner-managed poses no trouble when the owner represents the corporation. The owner represents all the relevant interests in the corporate entity. As a matter of fact, given that the owner represents all or mostly all the interests, she might actually be a better representative of the corporation than a lawyer who is not part of the corporation itself. As mentioned above, this Article makes the case for the small corporate defendant receiving a pro se right. But this does not mean the logic does not extend to large corporations.

https://www.huffpost.com/entry/detroits-unemployment-rat_n_394559

[https://perma.cc/X7CR-7ZXV], and Detroit Unemployment Rate Triple the National Average, NPR (Mar. 25, 2009), https://www.npr.org/templates/story/story.php?storyI $\mathrm{d}=102326093$ [https://perma.cc/D49B-4QPV].

270 Kennedy, supra note 262 , at 452 . "The cash fines in use today suffer from crippling flaws. They are inaccurate tools, hurting innocent parties other than shareholders. This inaccuracy calls their fairness into question." Id at 454 (highlighting the negative impacts of fines or other monetary consequences for companies on parties like employees). 
The large corporation has not only shareholders to represent, but also managers and employees. ${ }^{271}$ This is too important and difficult a task to be trusted to just any agent of the corporation. Only a trained lawyer can have the wherewithal to represent many diverse interests in a lawsuit.

We should not think that a non-lawyer manager would have difficulty representing the various interests at stake in a corporate lawsuit. But before turning to that exact point, it's helpful to articulate how a lawyer represents a corporation.

The attorney represents the interests of the corporation, not the constituents and not the shareholders. ${ }^{272}$ Rule 1.13(a) of the American Bar Association's Model Rules of Professional Conduct reads: "A lawyer employed or retained by an organization represents the organization acting through its duly authorized constituents." 273 Similar language appears in the New York Rules of Professional Conduct:

When a lawyer employed or retained by an organization is dealing with the organization's directors, officers, employees, members, shareholders or other constituents, and it appears that the organization's interests may differ from those of the constituents with whom the lawyer is dealing, the lawyer shall explain that the lawyer is the lawyer for the organization and not for any of the constituents. 274

These rules indicate that a lawyer should not prioritize one constituency over another but, instead, should think of her client as solely the corporate entity. 275 In the small owner-manager context, the interests of the corporate/partnership entity and the interests of the owner are one and the same, therefore, it should be easier for the lawyer to make adequate representation, For the same reason, it's easy for the owner herself to also appear pro se on behalf of the corporate entity. The public corporate context, by its very nature, is a difficult path to traverse for the lawyer. ${ }^{276}$

271 See id. at $448,452$.

272 MOdel Rules OF PROF'L CONDUCT r. 1.13(a) (AM. BAR ASS'N 2020).

273 Id.

${ }^{274}$ N.Y. RULES OF PROF'L CONDUCT r. 1.13(a) (2020).

${ }^{275}$ Court cases reinforce this notion of representing a corporation and not its shareholders or other constituents. Murray v. Metro. Life Ins. Co., 583 F.3d 173, 177 (2d Cir. 2009) (holding that MetLife's counsel did not become counsel to the policyholders as result of counsel's representation of MetLife, instead counsel only set out to represent the corporate entity MetLife); Evans v. Artek Sys. Corp., 715 F.2d 788, 792 (2d Cir. 1983) ("A 'corporate attorney'- whether an in-house lawyer or a law firm that serves as counsel to the company - owes a duty to act in accordance with the interests of the corporate entity itself. [The attorney's] client is the corporation."); Eurycleia Partners, LP v. Seward \& Kissel, LLP, 910 N.E.2d 976, 981 (N.Y. 2009) (holding that even in a partnership, counsel represent the partnership entity not the limited partners akin to the corporate shareholder context).

${ }^{276}$ For an extensive discussion of the difficulties that lawyers have in representing the corporate client, see generally Ralph Jonas, Essay, Who Is the Client?: The Corporate Lawyer's Dilemma, 39 HASTINGS L.J. 617 (1988). 
What does it mean to represent the interests of the corporate entity but not the interests of the shareholders or other constituents? This is not an easy question to answer and could be an article in and of itself. The only issue to consider here is whether a lawyer is more apt at answering this question than a manager or another executive that could appear on behalf of the corporation.

According to the team production theory of the firm, managers are the exact right people to represent the interests of the corporation. ${ }^{277}$ As a mediating hierarchy, their job is make sure all the constituents in a corporation are placated to the point of contributing efficiently to the firm. ${ }^{278}$ Managers and boards of directors are put in place precisely as substitutes "for explicit contracting that is especially useful in situations where team production requires several different team members to make various kinds of enterprise-specific investments ..."279 Again, the members of the corporation give these executives this power because they realize that without giving up control to a mediating hierarchy, there will be no corporation, and the rewards for the corporation (even with giving up control) are higher than not incorporating. ${ }^{280}$ The managers then, according to Blair and Stout, work for all team members (shareholders and employees alike) for the exact purpose to mediate disputes. ${ }^{281}$

This is exactly the task at hand when representing a corporation in a courtroom. The manager's day-to-day activities in a corporation mimic exactly the duties the lawyer for the corporation has in a courtroom. Why, then, would we think the non-lawyer representative (a pro se corporate agent) would have difficulty representing the varying interests of the members of a corporation? As a matter of fact, the manager (mediating hierarchy) is probably incredibly apt at doing exactly what needs to be done when she appears pro se for the corporation.

Moreover, the manager makes important decisions that have direct bearings on lawsuits all the time. They decide which lawyers should represent the corporation, they approve of briefs and counterclaims, they decide when, whether and how to settle, and they can even decide when to enter Chapter 11 bankruptcy proceedings. ${ }^{282}$ If this weren't sufficient, managers represent the

277 See Blair \& Stout, supra note 244, at 250.

278 /d. at $250-51$.

279 ld. at 278 .

280 See id.

281 Id.

282 Managerial discretion is a staple of corporate law. This is most readily seen in the business judgment rule. For extensive discussions of the business judgment rule, see Smith v. Van Gorkom, 488 A.2d 858, 872-73 (Del. 1985) ("[A] director's duty to exercise an informed business judgment is in the nature of a duty of care, as distinguished from a duty of loyalty."); Aronson v. Lewis, 473 A.2d 805, 812 (Del. 1984) ("It is a presumption that in making a business decision the directors of a corporation acted on an informed basis, in good faith and in the honest belief that the action was taken was in the best interests of the company."); Dodge v. Ford Motor Co., 170 N.W. 668, 684-85 (Mich. 1919) (upholding the shareholder primacy rationale for the business judgment rule); and Bayless Manning, The Business Judgment Rule in Overview, 45 OHIO ST. L.J. 615, 615-25 (1984). 
corporate entity even in court proceedings. When a corporation is brought to the stand for questioning, a manager or high-level executive appears in pro se manner to answer questions on behalf of the corporation. ${ }^{283}$

This response fails clearly for the owner-managed corporation and also fails for the large corporation.

\section{The Manager Might be Favorable to Shareholders}

A closely-related response to Part V.B.1 above might take the form that managers will be shareholder friendly. After all, maximizing shareholder profit is classically defined as the job of the manager. ${ }^{284}$ If this is the case, then maybe by requiring a lawyer, the legal system has exactly protected those low-level employees from inappropriate manager behavior.

On a first glance, this response fails for the owner-managed case. If the sole shareholder is also generally the only employee, her individual interests are exactly the corporation's interest as a whole. Therefore, by fiat, any action she takes in her own interest (be it one that favors the shareholders) advances all the relevant interests of each member of the corporation. Again, as mentioned previously, most companies are small and closely-held. ${ }^{285}$ These companies do not suffer from managers who favor certain constituents over others. Moreover, these are the exact companies that would have actively used the pro se right in the first instance. ${ }^{286}$

The criticism has more bite in the public and large corporate context. In that case, it could very well be argued that a manager would favor directors over others, after all, the directors likely hired the manager in the first instance. ${ }^{287}$ ? The argument relies upon the theory that the lawyer is better situated to protect all interests than the manager. In addition to the discussion above, two responses can be made at this critique.

First, one can argue that lawyers might be just as likely to favor shareholders as managers, or even favor managers themselves. The managers are the ones

\footnotetext{
283 See, e.g., FED. R. CIV. P. 30(b) (discussing corporate witnesses).

284 David R. Lea, Shareholder Wealth Maximization, in ENCYCLOPEDIA OF BUSINESS ETHICS AND SOCIETY (Robert W. Kolb ed., 2008).

285 Closely Held Corporations, supra note 226.

286 See supra Part I (discussing Drake v. Zen Bakeries, LLC and the attempted use of the pro se right by small shareholder companies).

287 See Mike Volker, The Board of Directors, SIMON FRASER U., https://www.sfu.ca/ $\sim$ mvolker/biz/bod.htm\#: :text=The\%20shareholders\%20own\%20the\%20company, in\%20t urn\%20appoint\%20the\%20managers [https://perma.cc/XVW4-GWHS] (last updated Aug. 8,2008 ) "The shareholders own the company and they appoint the directors who in turn appoint the managers." (emphasis omitted)); see also, e.g., OHIO REV. CODE $§ 1701.64(\mathrm{~A})$ (West 2020) (noting that the primary officers of a corporation are elected by the board of directors annually).
} 
who hire, monitor, and ultimately direct the lawyers. ${ }^{288}$ Since lawyers answer to the managers for the most part, even though their client is the firm, there is likely a risk of bias in favor of tactical moves and settlements deals that favor managers. ${ }^{289}$

Second, even if managers might pervert the process of representation, their actions are ripe for lawsuits by employees. When a manager appears pro se for a corporation and then favors shareholders over all other members, those members have a legal recourse against the corporation itself. They can always sue the corporation. ${ }^{290}$ However, if a lawyer were to represent the corporation and then fail to take into consideration all members of the corporation, low-level employees, and even mid-level ones, would have no recourse against the company or the lawyers. ${ }^{291}$ The company itself would have been the client and only the company would have any recourse against the lawyer. ${ }^{292}$ If the lawyer favored shareholders then there would be absolutely no recourse for other employees because only the shareholders could vote to sue a lawyer for malpractice. ${ }^{293}$

So, by giving the corporation a pro se right, we protect the interest of all members of the corporation by the actual representation and by the right to sue the corporation in case of particularly perverse representation.

288 This is because, by appearing pro se, the corporation itself has acted. Employees have contracts with the corporation and hence could bring a suit over the contractual relationships they may have with the corporation.

289 For a discussion of the pitfalls that corporate lawyers fall into when representing corporations and how they might favor some constituencies over others, see generally William H. Simon, Whom (Or What) Does the Organization's Lawyer Represent?: An Anatomy of Intraclient Conflict, 91 CALIF. L. REV. 57 (2003) (discussing the difficulty of representing organization clients consisting of constituents with conflicting interests).

290 This could be over contractual obligations or even wrongful termination. Note this is similar to a derivative suit, although a derivative suit would only be brought by shareholders. Shareholder Derivative Suits, JUSTIA, https://www.justia.com/banking-finance/securities/ shareholder-derivative-suits/ [https://perma.cc/9J6T-VXLB] (last updated Apr. 2018).

291 This is because the corporation itself wouldn't have acted, but the lawyer would. Hence, the only way a lawsuit could be brought against the lawyer's representation would be by the client, in this case, the corporation. And only shareholders along with management can bring a lawsuit on behalf of the corporation. See supra note 290.

292 Notably, only the client of a lawyer (the corporation in this case) can sue the lawyer for their representation. See Thomas R. Stauch, Matther A. Nowak \& Ryan C. Gentry, Can You Bring a Malpractice Claim Against a Lawyer who Was Not Your Lawyer?, NowaK \& STAUCH, https://www.ns-law.net/published-articles/can-you-bring-a-malpractice-claimagainst-a-lawyer-who-was-not-your-lawyer/ [https://perma.cc/YD4G-MLNK].

293 Again, this is because, for a derivative lawsuit, only shareholders with management approval can bring a lawsuit. See Shareholder Derivative Suits, supra note 290. Employees cannot bring a lawsuit on behalf of the company against a third party. See, e.g., id. 


\section{Sole Shareholders Already Have Limited Liability to Protect Themselves}

One might respond to an extension of pro se rights to small owner-managed defendant firms by pointing to the fact that they have limited liability protection which prevents the plaintiff from going personally to the sole shareholder/member in case the corporation cannot meet its obligations after the lawsuit. ${ }^{294}$

Although limited liability might offer some safeguards for the individual, it is clearly not enough for two reasons. First, even though limited liability protects the individual, it doesn't do the small owner-manager defendant really any good. Limited liability assists shareholders and owners when they have substantial wealth independent of the relevant corporate entity. ${ }^{295}$ Moreover, losing all of one's small business assets is clearly a personal detriment and certainly causes personal injury.

It's also worth pointing out that limited liability does not apply in the partnership context. Partners in a partnership face full recourse liability when they take any action. ${ }^{296}$ Yet, they too still cannot appear pro se. ${ }^{297}$

Second, even if we grant that limited liability protects the owner-manager that does not mean that extra protections via pro se rights are not still reasonable. As described in Part IV above, the whole notion of due process is to provide the defendant with all potential safeguards against government action. ${ }^{298}$ With this in mind, we simply need to see that pro se rights are another way to protect the small owner-manager. They are certainly not the only way.

There exists then no readily applicable reason why a business organization (particularly small owner-managed ones who are defendants) cannot represent themselves in court. Furthermore, granting corporations a pro se right affirmatively protects the exact interests the Founding Fathers were concerned with in writing the Sixth Amendment. Individual protection from government harm is the basis of the constitutional pro se individual right. ${ }^{299}$ If this is truly what we care about, then it seems only logical that we extend the right to corporations because doing so furthers the same goals.

${ }^{294}$ For extensive discussions on limited liability, see generally Easterbook \& Fischel, supra note 218 (discussing the valuable functions served by the rules of limited liability), and Paul Halpern, Michael Trebilcock \& Stuart Turnbull, An Economic Analysis of Limited Liability in Corporation Law, 30 U. TORONTO L.J. 117 (1980) (discussing the merits of the doctrine of limited liability in corporate law).

295 See Easterbrook \& Fischel, supra note 218, at 92.

296 See, e.g., REVISED UNIF. P'SHIP ACT $§ 306$ (a) (UNIF. LAW COMM'N 2013).

297 See, e.g., Eagle Assocs. v. Bank of Montreal, 926 F.2d 1305, 1309 (2d Cir. 1991).

298 See supra Part IV.

${ }^{299}$ See Faretta v. California, 422 U.S. 806,834 n.45 (1975). 


\section{CONCLUSION}

Corporations have been the subject of intense debate. In particular, various scholars and courts disagree as to whether we are to treat corporations as natural persons for purposes of constitutional law or something different. One such constitutional right that has gone unexplored is the right to represent oneself in a court proceeding. The classic view of the business organization as needing an agent to act on its behalf has prevented courts from extending pro se rights to corporations.

This Article has attempted to debunk these rationales both on doctrinal and empirical grounds. It has argued that the current rhetoric on a prohibition of a corporate pro se right is weak and misguided. This Article has argued for a shift of discussion from what makes corporations different than natural persons to why we have due process rights in the first instance.

Once we determine that pro se rights are meant to protect individuals from government action and from deprivations of life and liberty, we see that the same issues are at stake in the corporate context. Members of a corporation (particularly small owner-managed ones and partnerships) are at risk of personal deprivations of life and liberty when their companies are sued. As such, it's only logically consistent that we extend the pro se rights to corporations so that we provide these members with another means of due process protection. 